\title{
Benefits of Cover Crops in Soybean Plantation in Brazilian Cerrados
}

\author{
Pacheco, Leandro Pereira and Petter, Fabiano André \\ Federal University of Piaui \\ Brazil
}

\section{Introduction}

The demand for food overseas has been increasing due to the accelerated growth of population during the last decades, what has led to the incorporation of areas for agriculture by men and, above all, to the seek for increasing crop productivity. However, improper management of agricultural areas and climate changes have brought up a concern about the adoption of less harmful models of production, while talking about the worldwide environment.

The use of cover crops in areas in which soybean has been cultivated has become a widespread practice in several countries, mainly in tropical regions of the globe. In this chapter, we will focus on the use of cover crops in the Cerrado region of Brazil, since climate conditions of each region of the globe present different approaches to this subject. The high temperatures in these places promote an accelerated decomposition of soil organic matter, reducing fertility and increasing the emission of greenhouse gases into the atmosphere.

The use of cover crops in no-tillage soybean plantations, with no tillage and the presence of mulch on the soil surface, has brought to the Brazilian Cerrado areas a reduction in erosion, and it has increased the soil fertility (chemical, physical and biological attributes), the control of insects, diseases and weeds, and, also carbon sequestration from the atmosphere, due to the accumulation of soil organic matter (Bloom, 2002).

In Cerrado areas, in which there is a major occurrence of off-season with very high temperatures and low rainfall, from April to October, several techniques for the introduction of cover crops in soybean areas have already been tested. The presence of water stress after soybean harvest has hampered the establishment and growth of cover crops in succession, what makes necessary the use of species with fast grow th and resistance to drought stress. Moreover, the decomposition rate of mulch on the soil surface is high, due to high temperature and the effect of soil microfauna on plant debris.

Nutrient cycling promoted by cover crops is another important factor for agriculture, by absorbing nutrients on subsurface layers and then releasing them on the surface layers through decomposition and mineralization of their residues (Torres et al., 2008). Some species still have the potential to accumulate nitrogen through biological fixation, which contributes about how to increase soil fertility.

Given this, the use of crop production systems, which aim at the introduction of cover crops with high capacity for biomass production, becomes essential. The no-tillage system, since it 
does not turn over the soil, allows greater permanence of mulch on the soil surface, what contributes to its protection against the agents of erosion and to the accumulation of organic matter. The possibility of increasing soil organic matter promotes the carbon sequestration from the atmosphere and the reduction of greenhouse gases on the planet. This shows that agriculture has potential to contribute to food production and to a better standard of living of as for population, if conducted sustainably; using crop production systems that seek to reduce the impacts of human intervention on the environment.

\section{Soil management systems in the Brazilian Cerrado}

The occupation of the Cerrado took place more intensively in recent decades, emerging concern about the need of conservation practices to a sustainable agricultural system. The use of soil management systems, such as no-tillage (NT), has been done in an attempt to help increasing crop yield, reducing production costs and minimizing impacts of agriculture to rural and urban environment (Campos et al., 1995). According to Conab (2009), Brazil has grown more than 47 million hectares of grain crops in 2008/ 09, of which more than 25 million were under NT (FEBRAPDP, 2009). The conventional tillage (CT) recommends the use of implements that do the tilling of topsoil for planting annual crops, while the NT has been the only soil disturbance in the row (Figure 1), presence of biomass on the soil surface and crop rotation (Kluthcouski et al., 2000). These practices help protecting against soil erosion and plant health problems, particularly diseases and weeds (Severino et al., 2006), in addition to that, there is an increase in the availability of nutrients and organic matter in the soil (Torres et al., 2005). Crop rotation also provides diversification of economic activity in agriculture and rural property.
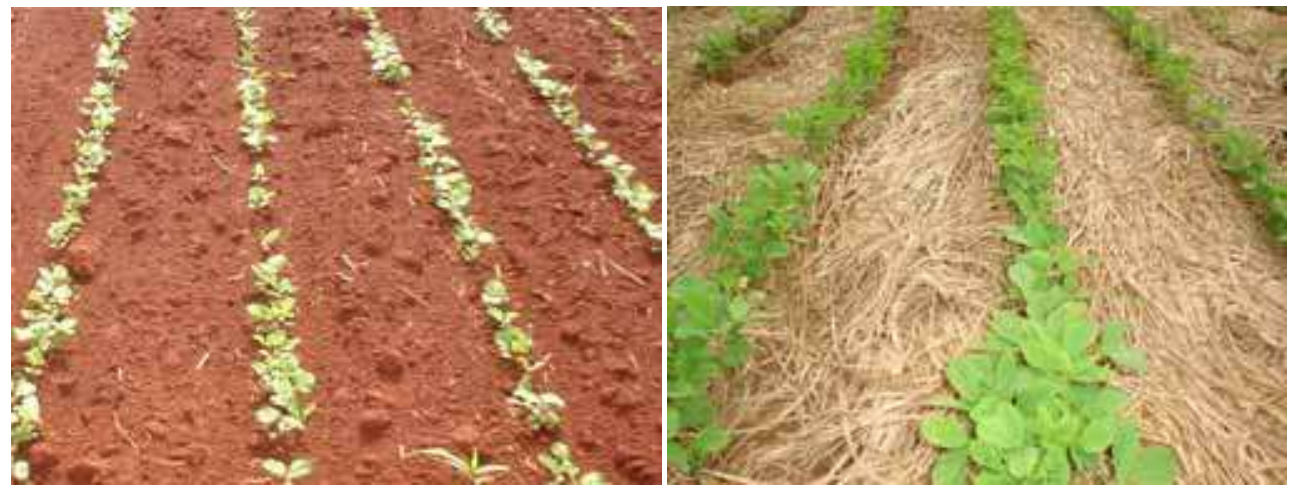

Fig. 1. Soybeans grown in conventional tillage-CT (left) and no-tillage-NT on Brachiaria ruziziensis (right) in the region of Rio Verde, GO, Brazil. (Photos: Leandro Pereira Pacheco)

Velini \& Pereira (2003) and Pacheco et al. (2009b) showed that the NT is even possible to keep problematic weeds under control, provided that they are employed in crop rotation programs combined with appropriate management and chemical control. Stone \& Silveira (1999) have observed a better use of water from the soil by bean plants under NT, although there was a lower rate of surface soil compaction in the CT. Carneiro et al. (2009) showed that the NT provides the best conditions for growth of soil microbes, due to the increased supply of organic residues and moisture, and less variation of soil temperature. Torres et al. 
(2005) and Boer et al. (2007) have noticed viability in the nutrients cycling by cover crops in NT, which may contribute to the rational use of fertilizers.

Studies have shown that the NT in the Cerrado presents some challenges. The producers of this region have faced some difficulties in production and in the maintenance of biomass on the surface, due to the high temperature and microbial activity in the decomposition, what makes the increase of soil organic matter difficult (Torres et al., 2005). Moreover, during the off-season between the months of April and September, characterized by a dry period with high temperatures, there are difficulties to the establishment of cover crops for formation of mulch (Pacheco et al. 2008; \& Machado \& Assis, 2010).

Improper use of the NT may compromise the natural resources and crop yield, due to physical, chemical and biological soil attribute quality reduction (Lamb et al., 2009). The use of cover crops sown in pre-harvest and after harvest of annual crops can provide improvements in these attributes, contributing to a more efficient use of water and nutrients, increasing crop productivity (Falleiro et al. 2003).

\section{Cover crops in no-till system in the Cerrado}

The cover crops used in the NT aim at protecting soil against erosion, and at contributing to the accumulation of organic matter and nutrients in the soil (Aita \& Giacomini, 2006). In the Cerrado region, the use of cover crops is more widely seen in succession annual crops during the dry season, between the months of March and September, a dry period with high temperatures, what has hampered the formation of biomass (Boer et al., 2007). Pacheco et al. (2008) and Machado \& Assis (2010) observed that the seeding of cover crops as early as possible, after soybean harvest, has resulted on a better performance of cover crops on biomass production, because of a better utilization of final rainfalls in April and May.

The high rate of decomposition of plant residues after management has also hampered the maintenance of biomass on soil surface (Crusciol et al. 2005; Boer et al., 2007, Torres et al., 2008). Some authors suggest that cover crops for this region must present a higher capacity for biomass production, and especially, a higher resistance to decomposition, which is related to the ratio of carbon and nitrogen (Crusciol et al., 2005, Torres et al ., 2005) or the degree of residues recalcitrance (Giacomini et al., 2003).

Cover crops sown during the off-season, has the ability to perform the cycling of soil nutrients by absorbing them on subsurface layers and then releasing them on the surface layers through decomposition and mineralization of their residues (Figure 2). However, Braz et al. (2004) show that there is a necessity of synchronization between the release of nutrients by cover crops and the demand for crop in succession, which may be related to species and sowing of cover crops, as well as to the time of desiccation management. Carpim et al. (2008) point out that the flowering is the ideal time for the management of the plant cover, due to the higher accumulation of biomass and nutrients.

There are several species of cover crops recommended for the use in the Cerrado, especially some grasses and legumes. The grasses of Brachiaria spp. stand out by presenting perennial habit, high resistance to drought and high biomass production (Timossi et al., 2007; Machado \& Assis, 2010). Pearl millet (Pennisetum glaucum) is notable for its rapid and early growth, drought tolerance and high biomass production (Boer et al., 2007). Legumes such as pigeonpea (Cajanus cajan) are highlighted in supplying nitrogen to plants, due to the presence of symbiosis with the nitrogen fixing bacteria (Aita \& Giacomini, 2003). C. cajan is a perennial legume with high resistance to water stress (Amabile et al., 2000) and it has the potential to be used in association with grasses for the formation of straw in the SPD. 


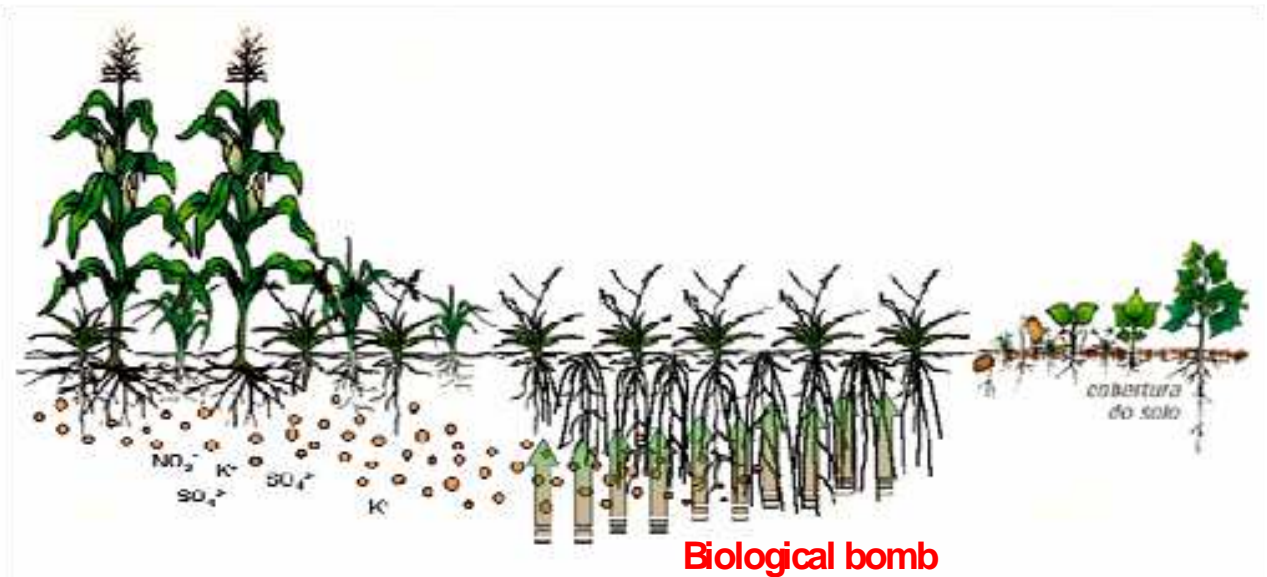

\begin{tabular}{|l|l|l|l|l|l|l|l|l|l|l|l|l|}
\hline Oct & Nov. & Dec. & Jan. & Feb. & Mar. & $\ldots$ & Jun. & Jul. & Aug. & Sep. & Oct. & Nov. \\
\hline
\end{tabular}

Fig. 2. Nutrient cycling in corn and soybeans in rotation cropped in no-tillage system with the use of cover crops during the off-season in Brazilian Cerrado. (Picture: João Kluthcouski).

\subsection{Pearl millet - Penissetum glaucum}

Pearl millet (Pennisetum glaucum) has been a cover crop widely used in off-season, because of its rapid growth, high biomass production and nutrient cycling in water deficit conditions. A Boer et al. (2007) study has pointed out in the Cerrado, the rapid growth of this kind, whose ADR 500 cultivar sown in April reached the level of $50 \%$ flowering to 51 days after emergence, dry matter production of $10,000 \mathrm{~kg} \mathrm{ha}^{-1}$ and with a capacity to accumulate in shoot $122 \mathrm{~kg} \mathrm{ha}^{-1}, 17 \mathrm{~kg} \mathrm{ha}^{-1}, 417 \mathrm{~kg} \mathrm{ha}^{-1}, 76 \mathrm{~kg} \mathrm{ha}^{-1}$ and $40 \mathrm{~kg} \mathrm{ha}^{-1}$ of nitrogen $(\mathrm{N})$, phosphorus $(\mathrm{P})$, potassium $(\mathrm{K})$, calcium $(\mathrm{Ca})$ and magnesium $(\mathrm{Mg})$, respectively.

Pacheco (2009) and Pacheco et al. (2009) observed that millet is a cover crop used in the Cerrado with greater capacity for biomass production (approximately 8,500 $\mathrm{kg} \mathrm{ha}^{-1}$ ), due to its rapid establishment and initial grow th up to 60 days after sowing, after soybean harvest.

Studies have shown that the time of millet sowing interferes in the ability of biomass production and nutrient accumulation. Torres et al. (2005), in the Cerrado region of Minas Gerais, observed that $P$. glaucum was able to accumulate over $150 \mathrm{~kg} \mathrm{ha}^{-1}$ and $50 \mathrm{~kg} \mathrm{ha}^{-1}$ of nitrogen when planted in October and March, respectively. These results are possible when considering the climate conditions are different in each planting period, mainly water availability for plant growth.

The high root growth of pearl millet can assist in unpacking the soil by the formation of preferential channels for water drainage and root growth of annual crops successors. According to Gonçalves et al. (2006), the use of millet to the decompression in cerrado soils is feasible, within thirty days getting high biomass and root length density in the compacted layers of soil to $1.60 \mathrm{Mg} \mathrm{m}^{-3}$. Bordin et al. (2008) observed that millet had higher root growth 
to a depth of $60 \mathrm{~cm}$, especially when we proceeded to chisel the soil surface. Pearl millet, because it is tolerant to the presence of aluminium $(\mathrm{Al}+3)$ in the soil, can promote high root growth, although most of the Cerrado soils have levels considered toxic $\mathrm{Al}^{+3}$ on the layers below $20 \mathrm{~cm}$ in profile (Figure 3).
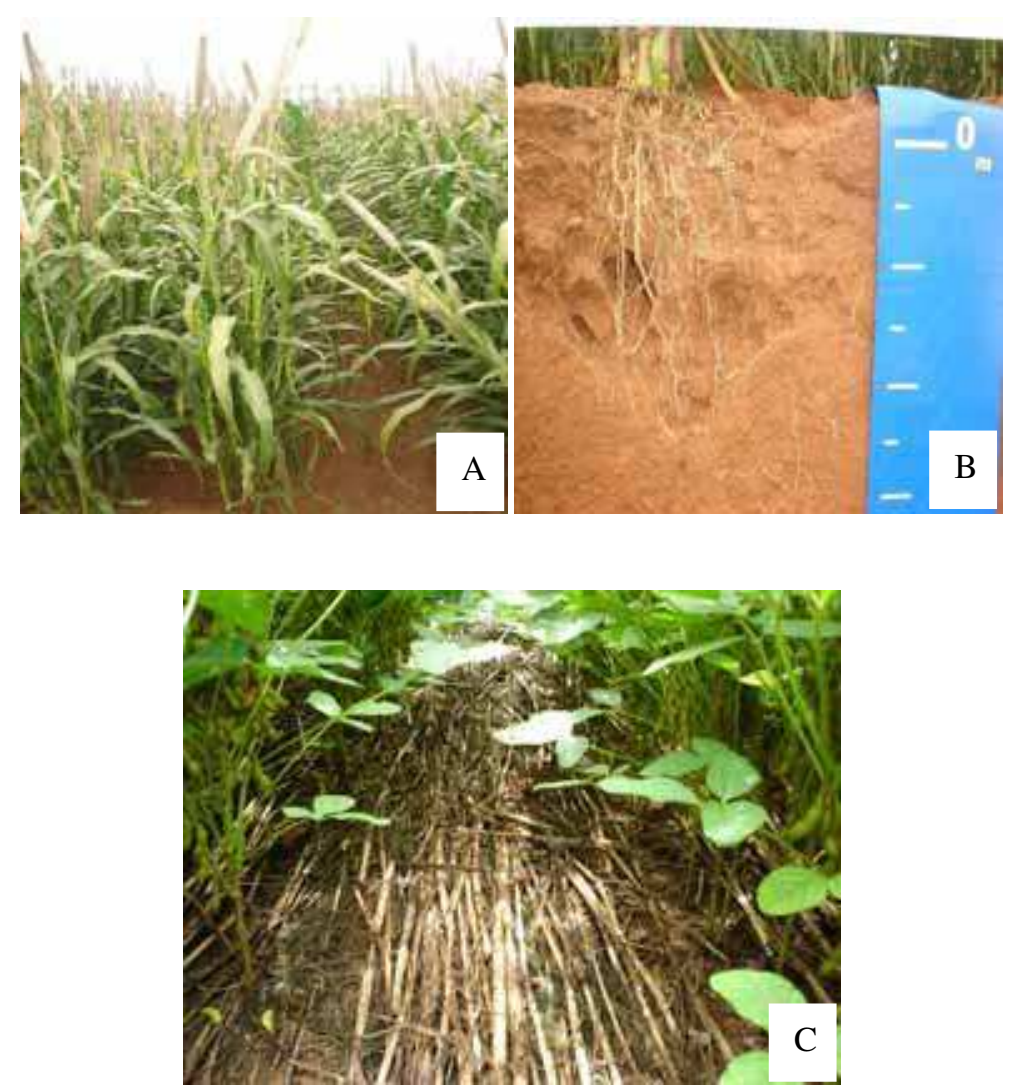

Fig. 3. Overview (A) and root grow th (B) plant millet (Pennisetum glaucum) through the soil profile, and soybean crops in no-till millet straw (C) (Photos: Leandro Pereira Pacheco).

According to Torres et al. (2008), this species has a high resistance to the decomposition of their residues, with half-life of the biomass on the soil surface up to 131 days after its management, due to its high $\mathrm{C} / \mathrm{N}$ ratio, which can result on greater persistence of mulch on the soil surface. However, the physiological cycle of this species cultivated in off-season, in the Cerrado region, causes the decomposition and nutrient release from biomass to be premature if compared to the time of sowing of annual crops (Timossi et al. 2007 ; Pacheco et al. 2008; Pacheco, 2009a). This feature can interfere in the presence of biomass on the soil surface in the end of the off-season and in the utilization of nutrients by annual plants cropped in succession (Figure 4). 


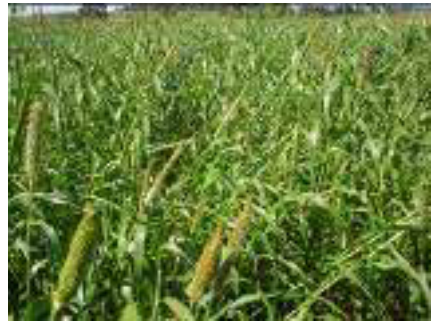

60 das/mayo

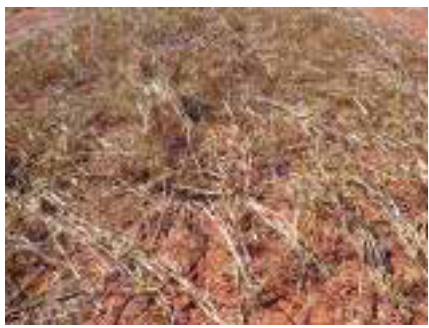

120 das/chly

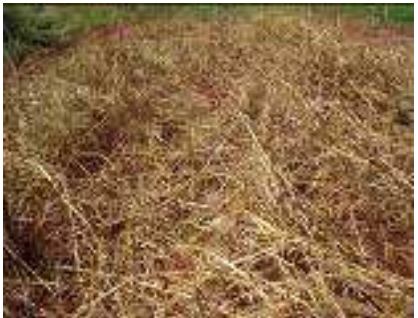

75 das/dune

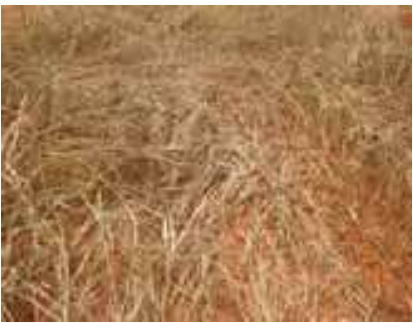

180 das/September

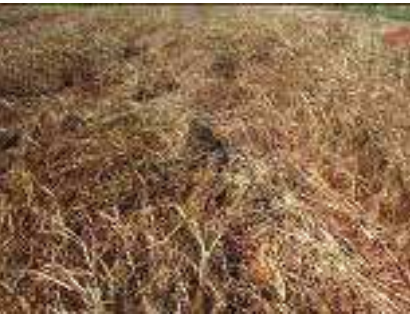

90 das/chne

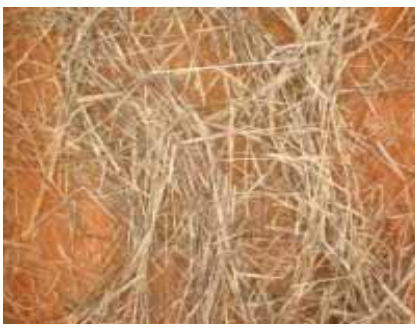

200 das/October

Fig. 4. Overview of the development of millet during the dry season, starting 60 days after sowing (DAS) by the end of the off-season, to 200 DAS in Goiânia, Brazil. (Photos: Leandro Pereira Pacheco).

\subsection{Brachiaria - Brachiaria spp.}

The use of cover crops with perennial habit, which are able to support drought stress and high light during winter and spring in Cerrado, such as the Brachiaria (Brachiaria brizantha and B. ruziziensis), can provide a significant accumulation of biomass and help delaying the beginning of its decomposition in relation to millet (Pacheco et al., 2008). According Timossi et al. (2007), the brachiaria species distinguished itself by a high adaptability to low soil fertility, an easy setting and a substantial biomass production during the off-season (Figure 5). These cover crops have great potentialto the maintenance of biomass in the soil, because its high $\mathrm{C} / \mathrm{N}$ ratio, which slows decomposition and increases the possibility of use in regions with high temperatures.

In studies of Torres et al. (2005), B. brizantha sown in March and desiccated at 110 days was not significant in biomass production and accumulation of nitrogen, $2,100 \mathrm{~kg} \mathrm{ha}^{-1}$ and $41 \mathrm{~kg}$ $\mathrm{ha}^{-1}$, respectively. The initial growth of this species is slow (Portes et al., 2000), however, the perennial habit enables its resume growth after the onset of rains in September, which can provide increase in biomass formation (Pacheco et al. 2008, Pacheco et al., 2009a).

Brachiaria species promotes the soil cover throughout the off-season and a significant increase in its biomass in the end of the dry season, with early spring/ summer rains that occur in the end of September through October in the Cerrado of Brazil. This is possible because of the perennial habit of this species and due to its high capacity of regrowing when the rainy season restarts, since there is a presence of vegetative buds in clumps and 

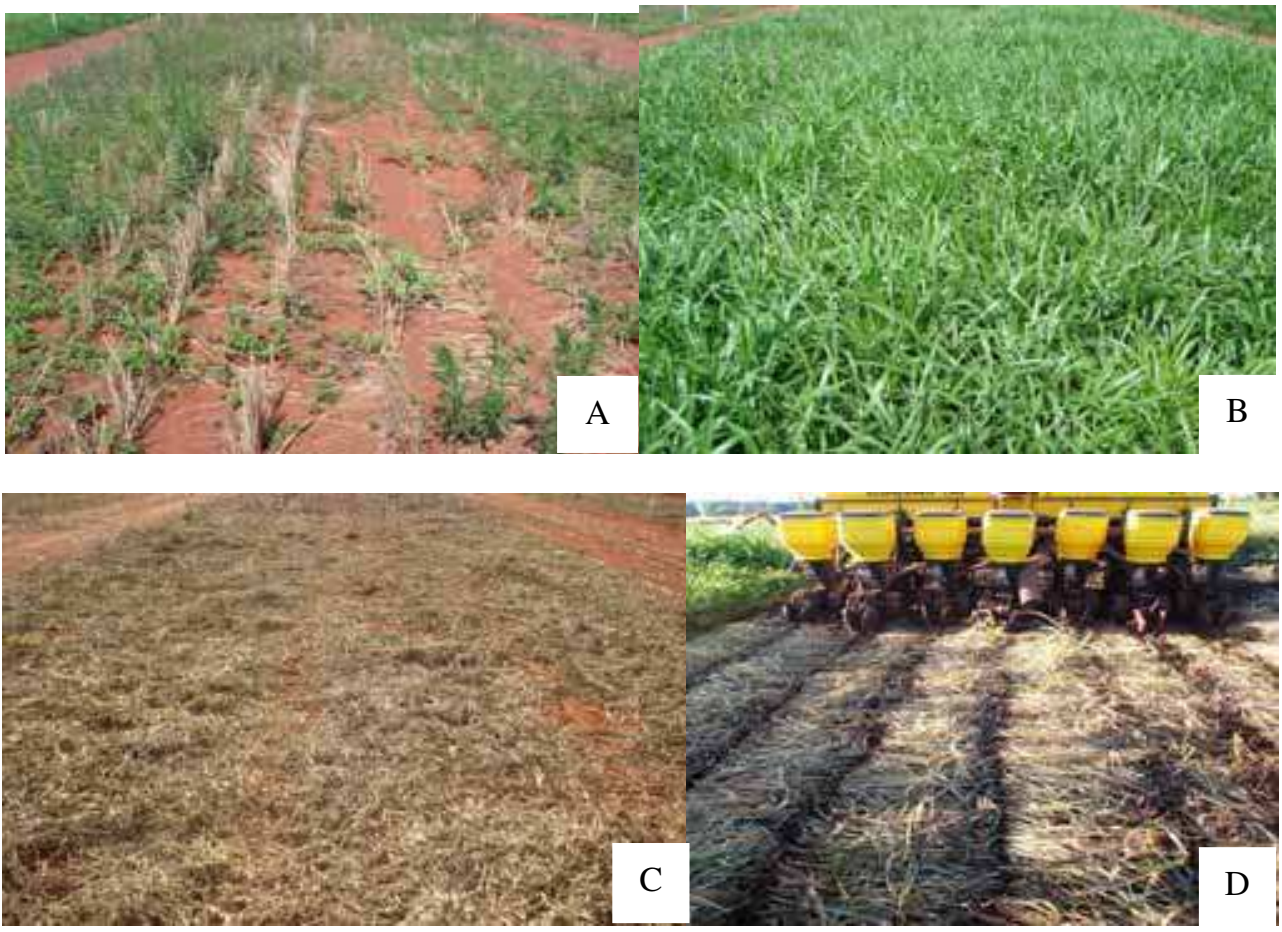

Fig. 5. Fallow area (A) and Brachiaria ruziziensis (B) the final of the off-season, in October, just before planting soybeans. B. ruziziensis desiccated (C) and soybean planting in no-tillage (D). (Photos: Leandro Pereira Pacheco).

stems of Brachiaria spp. (Portes et al., 2000). Moreover, when the first rain comes, plants have already developed root systems during the off-season, what favors the absorption of water and nutrients and the resumption of growth of aerial parts (Figure 6).

Comparing the performance of B. decumbens and B. brizantha to P. Glaucum, sown in March in the Cerrado region of São Paulo, Timossi et al. (2007) observed that the brachiaria was more efficient in biomass production (approximately $11,000 \mathrm{~kg} \mathrm{ha}^{-1}$ ). In the same study, $P$. glaucum has showed high biomass production at 110 days after sowing $\left(10,500 \mathrm{~kg} \mathrm{ha}^{-1}\right)$ in off-season, and when sowing the annual crop, there were only $3200 \mathrm{~kg} \mathrm{ha}^{-1}$ biomass for the NT. Pacheco et al. (2008) also observed high decomposition of the biomass of $P$. glaucum during the off-season in the Cerrado region of Goiás, noting that the earlier it was sowing in the off-season, the greater the loss of biomass by decomposition during the off-season was. Awork in the Cerrado in Goiás showed that the Brachiaria has the potential of biomass production between 9,0 and 14,0 ton ha-1 dry mass when planted after harvest of soybeans. As for the cycling of nutrients, Menezes \& Leandro (2004) observed that B. ruziziensis sown in December in the Cerrado had accumulated $240 \mathrm{~kg} \mathrm{ha}^{-1}, 30 \mathrm{~kg} \mathrm{ha}^{-1}, 406 \mathrm{~kg} \mathrm{ha}^{-1}, 64 \mathrm{~kg} \mathrm{ha}^{-1}$ and $48 \mathrm{~kg} \mathrm{ha}^{-1}, \mathrm{~N}, \mathrm{P}, \mathrm{K}, \mathrm{Ca}$ and $\mathrm{Mg}$, respectively, at 90 days after sowing. However, the growth of this species when sown in the off-season is different, because of the presence of long drought stress, what would result in lower values for biomass and nutrient recycling. 


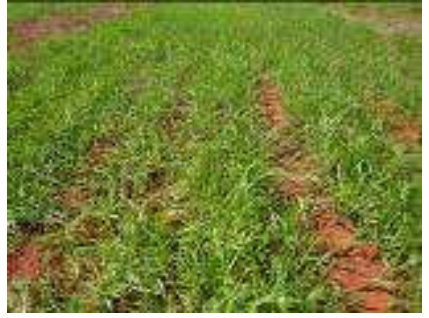

$60 \mathrm{das} / \mathrm{may}$

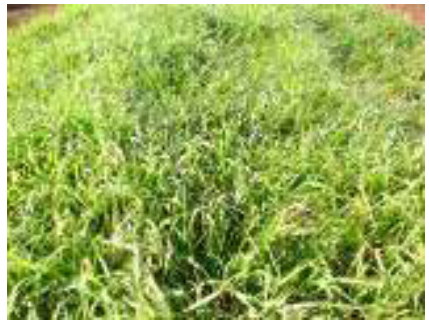

120 das/duly

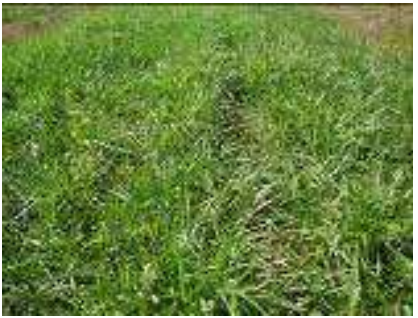

75 das/dine

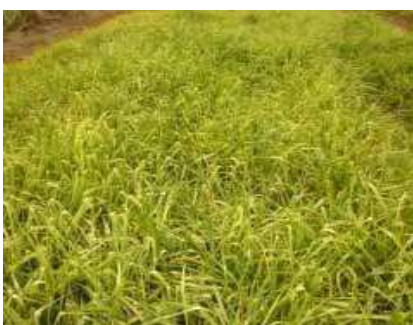

180 das/September

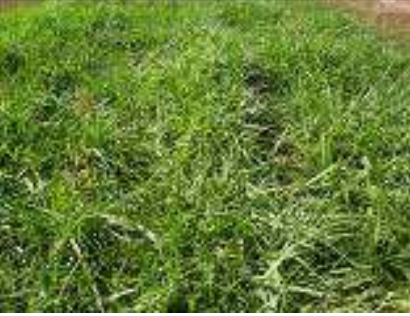

90 das/dine

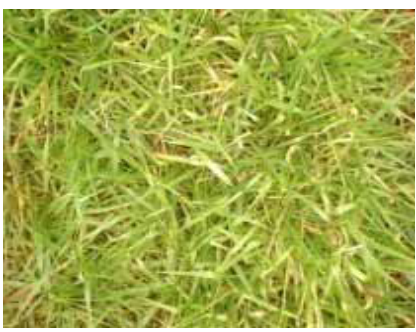

200 das/October

Fig. 6. Overview of the development of Brachiaria brizantha during the off-season, starting 60 days after sowing (DAS) by the end of the dry season, 200 DAS, in Goiânia, Brazil. (Photos: Leandro Pereira Pacheco).

Studies of Pacheco et al. (2009a) observed that Brachiaria (B. brizantha and B. ruziziensis) when sown after soybean harvest (March), get to accumulate until the beginning of the next harvest (October) in Cerrado, about $150 \mathrm{~kg} \mathrm{ha}^{-1}, 13 \mathrm{~kg} \mathrm{ha}^{-1}, 118 \mathrm{~kg} \mathrm{ha}^{-1}, 78 \mathrm{~kg} \mathrm{ha}^{-1}$ and $40 \mathrm{~kg} \mathrm{ha}^{-1}, \mathrm{~N}, \mathrm{P}$, $\mathrm{K}, \mathrm{Ca}$ and $\mathrm{Mg}$, respectively. After desiccation management for soybean planting, the $\mathrm{K}$ is the nutrient with the highest release rate in the soil, and $50 \%$ of the total accumulated time (halflife) is released in the soil up to 15 days after this operation. The other nutrients have slower release, showing a longer half life between 40 and 60 days after desiccation.

According to results of Reis et al. (2001), the high values of $\mathrm{N}$ accumulated by the biomass of $P$. glaucum, B. brizantha and B. ruziziensis can also be influenced by their abilities to join with $\mathrm{N}$-fixing bacteria by symbiosis, with predominance of species of Azospirillum and Herbaspirillun. As said by these authors, this process may contribute more than $40 \%$ and $20 \%$ of $\mathrm{N}$ accumulated in biomass of $P$. glaucum and Brachiaria spp., respectively.

B. brizantha presents difficulties as for desiccation management for soybean planting due to the high tolerance to glyphosate herbicide. Paraquat, due to its low translocation by phloem and xylem pathways, also fails in providing satisfactory control of ragweed. Chemical control using herbicides in this species may not be enough for total plant control, what provides conditions for its resumption of growth and regrowth during the development of soybean sown in succession (Figure 7). The herbicide glyphosate is a systemic mechanism, EPSP inhibitor (5-enolpyruvylshikimate 3-phosphate synthase). However, there are cases of plant resistance to this herbicide by reducing the mechanism of translocation via xylem and phloem, and also changes to the site of herbicide action in plants (Powles, 2008). Constantin et al. (2008) have reported difficulty in controlling Brachiaria species by glyphosate. 


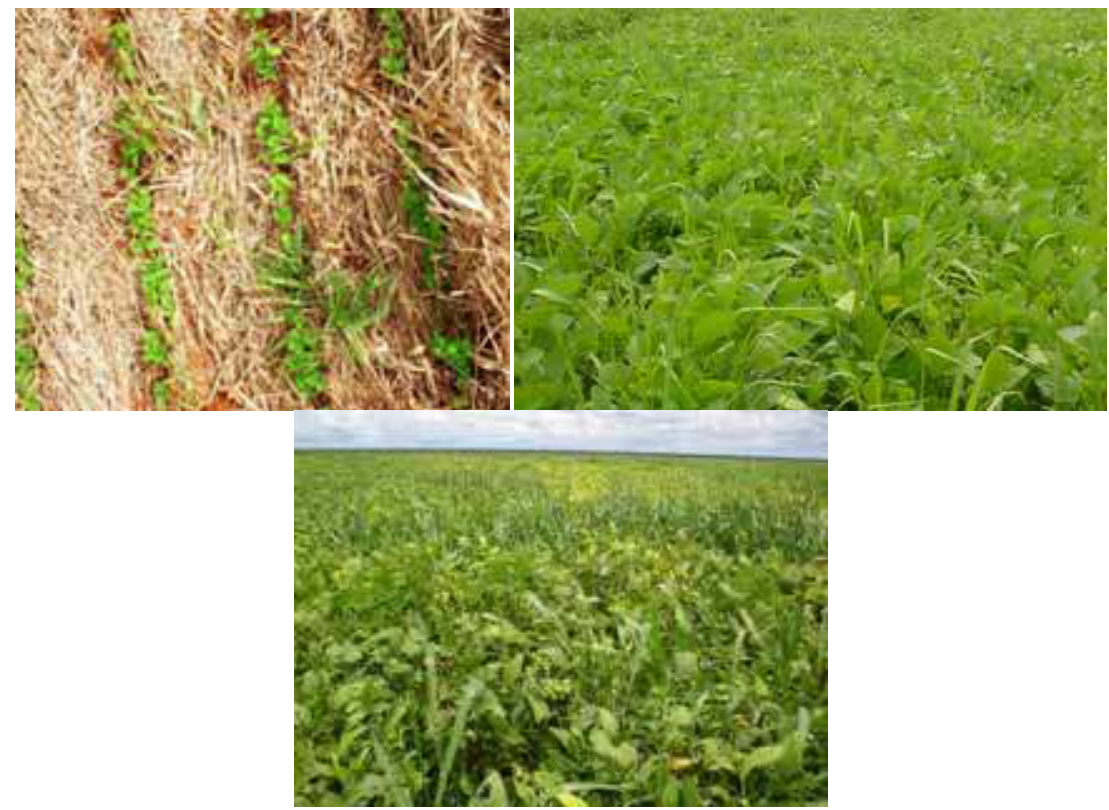

Fig. 7. Brachiaria brizantha regrow th after desiccation management with the use of glyphosate for soybean planting. (Photos: Leandro Pereira Pacheco).

These results demonstrate that $B$. brizantha needs to be managed so that plants can absorb and translocate the herbicide desiccant to the lateral buds in clumps, to prevent their sprout and interference in the growth of annual crops in succession. Increasing the dose of the herbicide may not be ideal, as described in works of Constantin et al. (2008), which show that high doses of glyphosate desiccation brachiarias management can interfere with growth and grain productivity of soybeans and corn. Moreover, the species B. ruziziensis single or intercropped with $C$. cajan emerges as a good choice for high production of biomass and ease of management for the SPD in Cerrado, contributing to reduce the soil erosion caused by rains that occur mainly in the early grow th stages of annual crops.

Another obstacle in the use of Brachiaria brizantha is in plantability of soybeans on its biomass. It seems that this plant has a high coverage rate of formation of clumps, what makes seed deposition difficult when soybean planter is sowing, leaving it on the soil surface (Figure 8). It is recommended, while sowing $B$. brizantha during the off-season, to use a higher density of plants to prevent the formation of clumps and to facilitate soybean planting as for the next harvest. Furthermore, the brachiaria can induce initial soybean seedlings etiolating in no-tillage system, because of excessive shading caused by the mulch in the row. In order to reduce this problem, it is recommended not to allow excessive growth of Brachiaria after the resumption of rains, carrying out it desiccation at the right time. Another option would be the use of implements to grind the mulch after desiccation, resulting in a homogeneous distribution of biomass on the soil, what would make the process of sowing easier. However, one needs to carry out this operation in required intervals since it is necessary to have the herbicide applied in desiccation translocated via phloem to the growing parts of $B$. brizantha, preventing its regrowth during the growth of soybean sown in succession. 


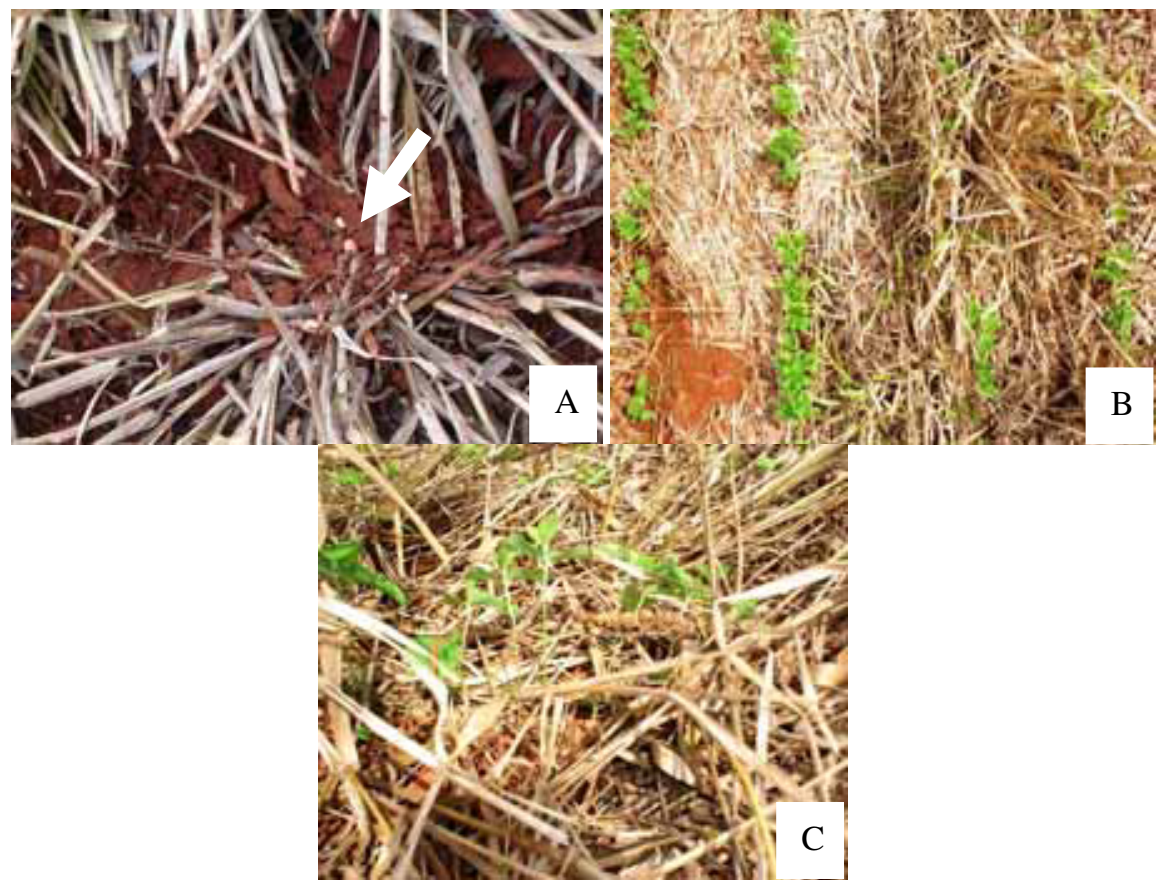

Fig. 8. Failures in the soybean seed deposition at sowing by the planter (A), reduction of stand (B) and soybean seedlings etiolation(C) under no-tillage on mulch of Brachiaria brizantha. (Photos: Leandro Pereira Pacheco).

\subsection{Pigeon pea - Cajanus cajan}

The Cajanus cajan is a perennial legume with the potential to be used as cover crop in the NT, since it presents a high resistance to drought and it performs the biological nitrogen fixation (Henriksen et al., 2002). Torres et al. (2005) showed that C. cajan reached $62 \mathrm{~kg} \mathrm{ha}^{-1}$ $\mathrm{N}$ in its biomass at 110 days after planting in off-season. Menezes \& Leandro (2004) also observed that excessive use of grasses in the production systems results in competition for $\mathrm{N}$ by plants during the process of organic matter mineralization.

Studies have shown increases in opportunities in biomass, rate of ground cover of C. cajan, due to its resumption in growth after the early spring-summer rains (Bordin et al., 2008). This feature is important to cover crops in Cerrado, since it reduces the mineralization process and, above all, allows greater biomass and nutrient accumulation during the offseason for the NT in annual crops in succession.

Legume species of Brachiaria spp. with perennial legumes such as C. cajan (Figure 9) can provide high biomass production (Amabile et al., 2000) and nitrogen biologically fixated in the soil accumulation (Henriksen et al., 2002). Gama-Rodrigues et al. (2007) showed that the introduction of leguminous cover crops increased the quality of its residues, due to higher supply of N, P and Ca to the soil.

By consorting legumes and grasses, a $\mathrm{C} / \mathrm{N}$ intermediate ratio biomass, the same as single crop species can be obtained (Figure 9). This characteristic increases the nutrients release to the soil after the desiccation of cover crops for planting annual crops, what would allow a 
reduction in the need of using fertilizer. Espindola et al. (2006) highlighted the potential of the herbaceous perennials in the release of nutrients for crops successor, due to the chemical composition of the residues. In this study, the nutrient releases are correlated to the levels of cellulose $(r=-0.92)$, hemicellulose $(r=-0.95)$ and $\mathrm{C} / \mathrm{N}$ ratio $(\mathrm{r}=-0.99)$. In addition, Bordin et al. (2008) pointed to the pigeon pea as a cover crop that promises to be satisfactory at decompressing soil layers, considering its aggressive root system.

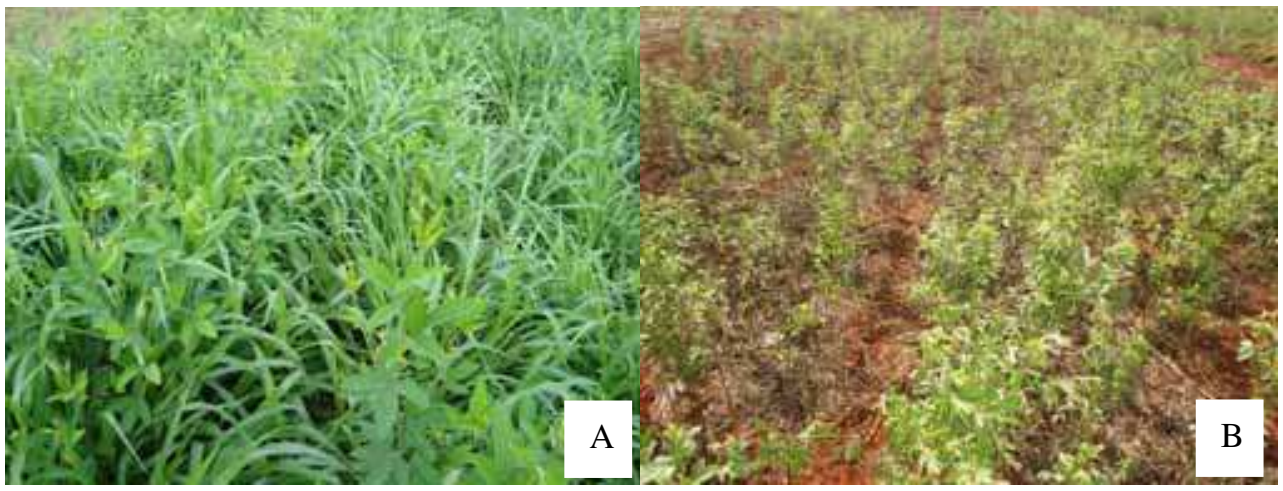

Fig. 9. C. cajan and B. ruziziensis in consortium during the off-season in Brazilian Cerrado (A) and $C$. cajan resistance to the application of glyphosate in desiccation management for soybean seeding (B) (Photos: Leandro Pereira Pacheco).

Some care must be considered while talking about the use of pigeon pea. As its initial growth is slow and it is sensible to photoperiod, we recommend its use on those occasions when you can sow it earlier, so the species can develop the first 60 days after sowing in soil moisture conditions. Important information is the resistance of this species to the herbicide glyphosate (Figure 9). Given this, to its desiccate management for soybean planting it is recommended the use of herbicides with other action mechanisms, such as paraquat and diquat.

\subsection{Crotalarias - Crotalaria juncea, C. spectabilis and C. ochroleuca}

The crotalarias are cover crops widely used in the Cerrado, because it is a legume with rapid growth, high biomass production, and it promotes the nitrogen biological fixation in the soil. The Crotalaria can be grown alone or in consortium with other cover crops, such as the brachiaria both in pre-harvest and after the soybean harvest. Several research studies have shown that crotalaria can produce between 5,0 to 6,0 ton ha-1 when sown in the fallow biomass of the Cerrado (Figure 10).

It's a species of short days, photoperiod sensitive, capable of producing more biomass when planted in October/ November in the Cerrado of Brazil. Some research studies indicate that there is a reduction of biomass production by this species when sown in the end of the rainy season (March), due to the reduction of photoperiod and less water availability for plant growth. Studies of Amabile et al. (2000) observed a reduction of more than 50\% of biomass production when comparing crotalaria sowing in the beginning and in the end of the rainy season, November and March, respectively. 


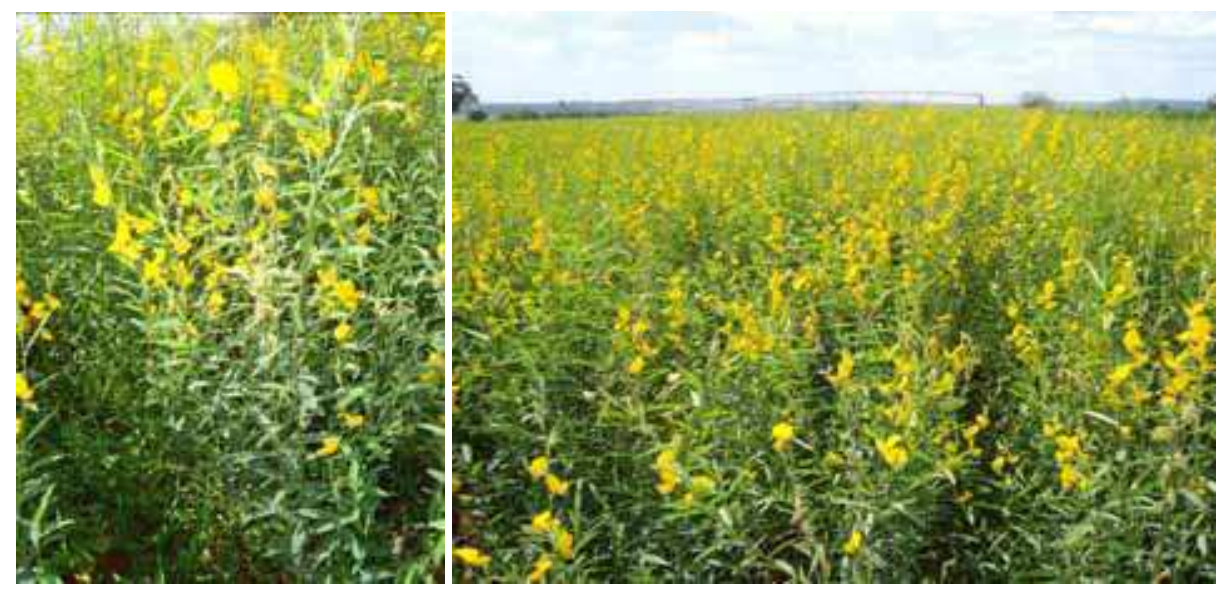

Fig. 10. Crotalaria juncea in flowering fenological stage (Photos: Leandro Pereira Pacheco).

Crotalaria presents high capacity to biological nitrogen fixation through associations with bacteria. Researches show that the increase of nitrogen in the soil by this pathway can be up to $165 \mathrm{~kg} \mathrm{ha}^{-1}$. Although soybean also performs the biological fixation of nitrogen, the increase of this element to soil favors the accumulation of organic matter, which favors the fertility of the Cerrado soils. In agricultural areas newly incorporated into the soybean, it becomes necessary to use the seeds with inoculant bases nitrogen fixing bacteria.

The continuous use of crotalaria may provide some problems regarding the control of insects and diseases. Some nematodes that cause damage in soybean have shown ability to colonize and multiply in the roots of crotalaria. Given this, it's recommended to use this cover crop in rotation with other species in order to promote the breaking of the microorganism cycle and pest population increasing.

Some studies indicate the feasibility of consortium with crotalaria and brachiarias during the off-season in Brazilian Cerrado. This measure aims at combining the high capacity for biomass production of Brachiaria and the possibility of increased biological nitrogen fixation promoted by crotalaria. However, further studies are needed to be able to define the best operating consortium, as for the ideal density of plants of each species and form of planting.

\section{Soybean crop oversowing used as a technique to biomass formation in no- tillage}

The introduction of cover crops in the Cerrado has presented several difficulties. The restricted water availability after harvesting the annual crops may, in some regions, markedly impair the growth of cover crops sown in the period. Given this, systems that can optimize the use of late season rains can contribute to biomass production during the offseason. The introduction of cover crops at an earlier time in soybean crops, immediately before harvest, through consortium, may be a key factor for the success of the system.

Legume cover crops in early stages of soybean development have originated serious problems. The researches results observed that the photosynthetic mechanism for soybean $\mathrm{C}_{3}$ carbon fixation accumulates less biomass if compared to cover crops used in the Cerrado, like the millet and the brachiaria. These characteristics provide limited competitive capacity of the legume in relation to cover crops, what is a major factor in the failure of soybean in 
consortium (Portes et al., 2000, Pacheco et al., 2008). Moreover, the process of grain harvest is significantly affected by low cutting height of the harvester machine platform, causing considerable loss of harvest efficience(Figure 11).
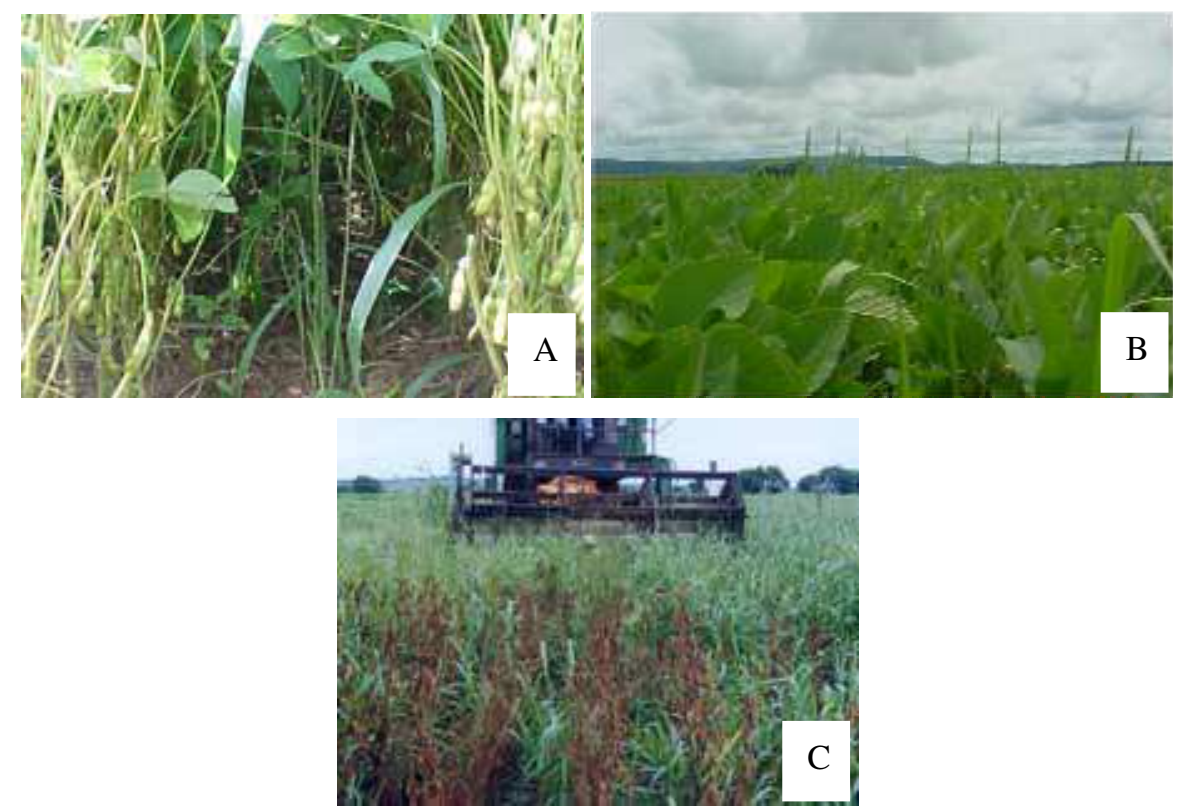

Fig. 11. Problems in the consortium between soybean and brachiaria: competition between species, causing yield losses in soybean (A and B), difficulties in the process of grain harvesting because the excess biomass (C). (Photos: Embrapa Arroz e Feijão).

The cover crops oversowing, when physiological maturity of soybean already exists (beginning of defoliation: R7 stage), seems to be a promising alternative consortium, providing greater flexibility in the operational schedule of the culture, especially in the process of grain harvest (Figure 10). The success of the system depends mainly on climatic conditions since the eve of sowing until 10 days after emergence of cover crops, seed germination and plant growth on soil surface.

The work of Lara-Cabezas (2004), with pelleted seeds of millet, IAPAR (2005), Trecenti (2005) and Pacheco et al. (2008), focused on eight cover crops, pointed oversowing as a viable alternative to address the maintenance of trash in the SPD. However, to fulfill the oversowing, it becomes necessary to use species that showgood adaptation to consortium cropping, without negative effect in the annual crop (Trecenti, 2005); tolerant to drought, because its implementation will coincide with the start of the dry season (Lara-Cabezas, 2004); produce high amounts of biomass for soil cover (Gazatta et al. 2005; Perin et al., 2004) and have the ability to forage for feeding animal in winter. In addition to that, there are several questions about the conditions that optimize the use of this practice, as the amount of seed and the behavior of ideal cover crop oversowing at different times, what is directly connected to the implantation of soybeans, the delay will result in greater climate risk for the development of cultivated species for formation of mulch. 
Pacheco et al. (2008) showed that the occurrence of dry spells after extensive cover crops oversowing on soybean resulted in reduction of emergence of plants. This is because, when the process of seed germination starts there is the rupture of seed coat and the radicle protrusion, which, in turn, is very sensitive to desiccation. Considering that seeds in oversowing are on the surface of the soil, a prolonged period of drought may promote the death of the seedlings germinated recently, causing significant stand reduction, what can compromise the technique success. To reduce these effects, the amount of cover crops seeds used on soybean oversowing needs to be larger in order to compensate for possible losses of seed germination and plant establishment.

During cover crops oversowing, if seeds have the possibility of germinating due to climatic conditions and seedlings get established, there have been significant gains in the ability of plants to accumulate biomass in coverage for the NT. In this way of sowing, plants have increased utilization of final harvest time rains to develop, increasing the growth of shoots and roots, allowing a larger resistance to water stress during the off-season and increases in biomass accumulated until the next harvest.

The distribution of seeds of cover crops oversowing on soybean can be performed using an air-plane or implements pulled by tractor. The advantage in aerial application is the agility and the absence of kneading in culture. However, the application cost is higher.

Thus, the search for strategies for the implementation of cover crops in the off-season may represent important alternative to the efficient mulch production to the NT in the Cerrado, without interference on the annual crop. This certainly is encouraging its adoption on a
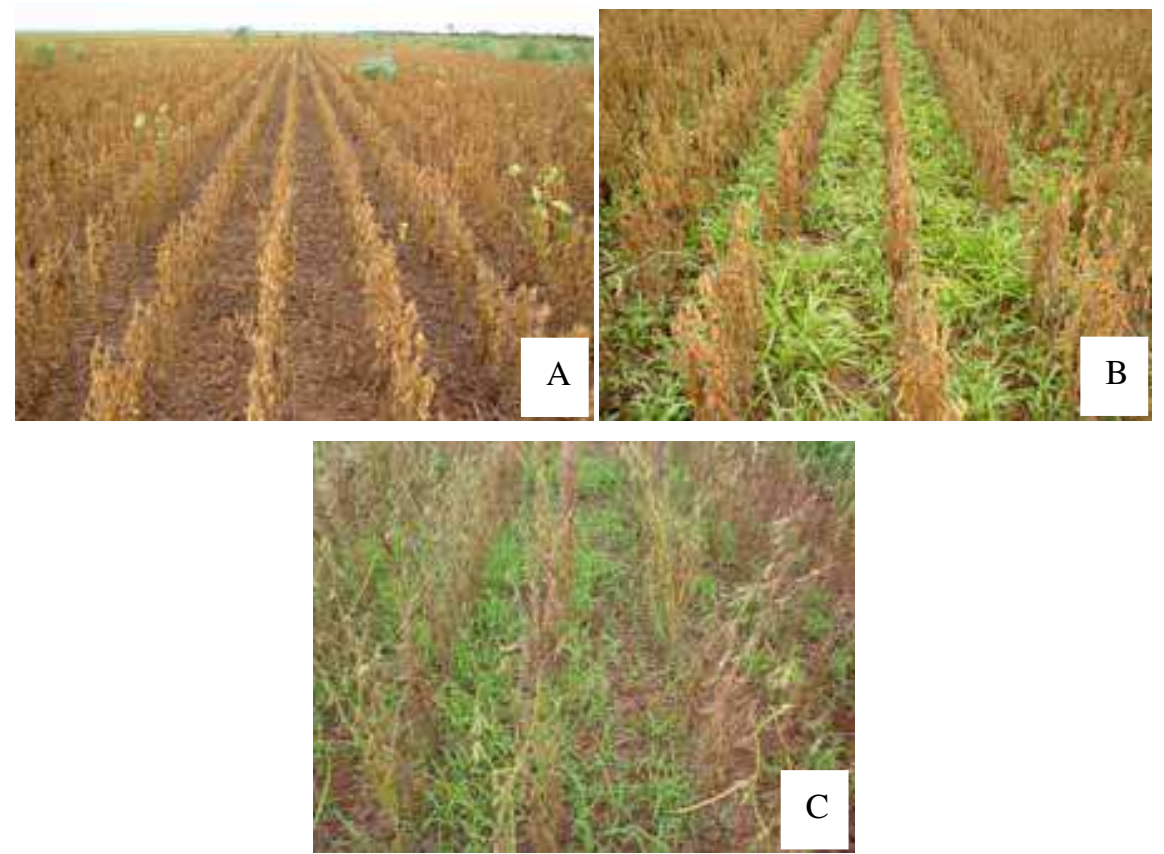

Fig. 12. Comparison of soybean single (A) and the use of B. ruziziensis (B) and P. glaucum (C) on soybean oversowing at realized in physiological maturity Stadium-R7-onset defoliation. (Photos: Leandro Pereira Pacheco). 
larger scale by farmers, especially those who grow genetically modified soybeans, for which the use of post-emergence gliphosate culture eliminates the possibility of simultaneous consortium with cover crops. In this case, the main option for consortium of soybean and cover crops is oversowing.

\section{Improvements in soil quality promoted by cover crops}

Cover crops have important functions in agricultural systems, not only by being inserted in management plans as an example of no-tillage, acting as one of its basic premises, which is the constant maintenance of these plants in cultivation areas, but also by providing benefits to the soil.

The effects of cover crops are not restricted to their protective effect on the soil surface, preventing the direct impact of rain drops on the soil, promoting the breakdown of particles and consequently reducing erosion and water evaporation from the soil. These plants have a direct influence on the physical, chemical and biological soil attributes, as well as helping to control weeds through the suppressive effect it has on them and, in many cases, due to their allelopathic effect through the release of chemicals compounds in the soil.

The importance exerted by the cover crops was highlighted as the effects of a predatory and extractive agriculture have intensified with regard to soil conservation. The intense anthropogenic activities on agricultural land without proper planning of land use has led to a process of degradation of its productive capacity (Kluthcouski \& Stone, 2003), generating losses on the more fertile layers of the soil, , those coming to $200 \mathrm{Mg} \mathrm{ha}^{-1}$ year-1 (Franco \& Campello, 2005). In tropical and subtropical regions, the effect of inadequate soil management gets worse mainly by the loss of organic matter $(\mathrm{OM})$, since the mineralization rate of $\mathrm{OM}$ reaches high levels, due to high temperature and microbial activity in the decomposition of residues, reducing the amount of these compounds in the soil (Torres et al., 2005). The OM soils in these regions account for approximately $80 \%$ of cation exchange capacity (CEC).

The maintenance of cover crops contributes to an increase of vegetable residues to the soil which will become OM stable, contributing to the maintenance of high levels of fertility and crop productivity.

\subsection{Soil physical attributes}

The soil physical attributes are significantly influenced by management type, and the structures of the initial aggregate feature that suffers most of the change, what eventually can influence on a number of other parameters. According to Kluthcouski \& Stone (2003), the physical characteristics of soil are interdependent, and as said by Vieira (1985), the modification of an attribute leads to the modification of all the others.

Therefore, the presence of cover crops istself, does not necessarily affect soil characteristics positively, it is necessary to give emphasis to the type of management that will be adopted for this system. Several parameters have been used to assess the sustainability of production systems, including assessing the state of soil aggregation, through the stability of aggregates (Moreira et al., 2009) and S index (Dexter, 2004), making possible the comparison of different management practices and soil physical characteristics. According to Dexter (2004), values of S considered as indicators of good quality structures are above 0,035 .

The incorporation of crop residues to plant hedges using implements that stir the soil tends to lose its original structure, fractionating aggregates into smaller units, generating a 
reduction in macroporosity, microporosity and an increase in density (Carpenedo \& mielniczuk, 1990). In conventional tillage, where soil disturbance is the basis of the practice, the influence of cover crops is not manifested to such an extent and vary from species to species, mainly due to morphological and physiological characteristics of the root system (Table 1).

\begin{tabular}{|c|c|c|c|c|c|c|c|c|c|}
\hline \multirow{2}{*}{ Trat. } & \multirow{2}{*}{$\begin{array}{c}\text { BS } \\
(\mathrm{kg} \mathrm{ha-1)}\end{array}$} & \multirow{2}{*}{$\begin{array}{l}\text { Dept. } \\
\text { (cm) }\end{array}$} & $\mathrm{PT}$ & MI & MA & Ds & Sindex & DMP & $>2 \mathrm{~mm}$ \\
\hline & & & $\mathrm{m}^{3} \mathrm{~m}^{-3}$ & $\mathrm{~m}^{3} \mathrm{~m}^{-3}$ & $\mathrm{~m}^{3} \mathrm{~m}^{-3}$ & $\mathrm{Mg} \mathrm{m}^{-3}$ & ------- & $\mathrm{mm}$ & $\%$ \\
\hline \multirow{3}{*}{$\mathrm{PO}$} & \multirow{3}{*}{1.942} & $0-10$ & 0,462 & 0,358 & 0,101 & 1,44 & 0,023 & 1,7 & 25,2 \\
\hline & & $10-20$ & 0,449 & 0,401 & 0,048 & 1,47 & 0,020 & 2,2 & 36,6 \\
\hline & & $20-30$ & 0,551 & 0,396 & 0,055 & 1,47 & 0,020 & 1,8 & 28,5 \\
\hline \multirow{3}{*}{$\mathrm{CR}$} & \multirow{3}{*}{4.430} & $0-10$ & 0,465 & 0,405 & 0,060 & 1,43 & 0,022 & 1,7 & 27,9 \\
\hline & & $10-20$ & 0,444 & 0,395 & 0,049 & 1,48 & 0,018 & 2,1 & 33,9 \\
\hline & & $20-30$ & 0,448 & 0,392 & 0,056 & 1,47 & 0,018 & 2,0 & 32,5 \\
\hline \multirow{3}{*}{ GD } & \multirow{3}{*}{3.528} & $0-10$ & 0,473 & 0,405 & 0,067 & 1,41 & 0,023 & 1,5 & 21,3 \\
\hline & & $10-20$ & 0,461 & 0,405 & 0,056 & 1,45 & 0,022 & 2,0 & 32,4 \\
\hline & & $20-30$ & 0,454 & 0,401 & 0,053 & 1,46 & 0,021 & 1,9 & 30,9 \\
\hline \multirow{3}{*}{$\mathrm{MU}$} & \multirow{3}{*}{2.993} & $0-10$ & 0,481 & 0,348 & 0,133 & 1,41 & 0,280 & 2,0 & 33,2 \\
\hline & & $10-20$ & 0,471 & 0,383 & 0,088 & 1,34 & 0,022 & 2,3 & 38,3 \\
\hline & & $20-30$ & 0,461 & 0,362 & 0,099 & 1,44 & 0,018 & 2,1 & 33,8 \\
\hline \multirow{3}{*}{ SO } & \multirow{3}{*}{13.250} & $0-10$ & 0,508 & 0,389 & 0,120 & 1,31 & 0,026 & 2,4 & 41,8 \\
\hline & & $10-20$ & 0,447 & 0,394 & 0,053 & 1,48 & 0,019 & 2,6 & 44,7 \\
\hline & & $20-30$ & 0,443 & 0,371 & 0,072 & 1,49 & 0,019 & 2,1 & 37,4 \\
\hline
\end{tabular}

Table 1. Dry biomass (BS) cover crops (PO - fallow, CR - crotalaria, GD - pigeon pea, MU velvet and SO - sorghum), total porosity (PT), (MI), macroporosity (MA), bulk density (Ds), the Sindex, mean particle diameter (DMP) and aggregates larger than $2 \mathrm{~mm}(>2 \mathrm{~mm})$ of a soil at different depths evaluated. From: Moreira et al. (2009).

The NT allows the cover crops to be incorporated into the system without soil disturbance, not affecting the soil structure. In the Cerrado, this fact has great importance due to rapid decomposition of crop residues as a function of temperature and humidity. The rate of decomposition can be reduced not only by the practice of non-incorporation of crop residues to the soil, but also, by the implementation of species with high $\mathrm{C} / \mathrm{N}$.

However, with no soil disturbance it is common in the NT the formation of compacted layers, mainly caused by traffic of agricultural machines in the crop areas. Soil compaction has been reported by many researches (Andrews et al., 1998, Bell et al. 1994; Richart et al., 2005) as a soil physical factor that limit crop productivity. Therefore, it is convenient to use plant species that have aggressive root system and high biomass production. The use of different management and species of cover crops can reduce soil compaction as shown in Table 2. According to Amado et al. (2001), different cover crops affect differently the stability of aggregates. 


\begin{tabular}{ccccccccc}
\hline \multirow{2}{*}{ Trat } & \multicolumn{7}{c}{ Soil layers $(\mathrm{m})$} \\
\cline { 2 - 9 } • & $0,0-$ & 0,10 & \multicolumn{2}{c}{$0,10-0,20$} & \multicolumn{2}{c}{$0,20-0,30$} & $0,30-0,40$ \\
\cline { 2 - 9 } & 2004 & 2007 & 2004 & 2007 & 2004 & 2007 & 2004 & 2007 \\
\hline T1 & 3,16 & 1,29 & 5,97 & 3,96 & 4,12 & 4,23 & 5,14 & 4,10 \\
T2 & 3,54 & 1,45 & 5,72 & 4,70 & 4,25 & 4,42 & 3,66 & 4,32 \\
T3 & 3,25 & 1,22 & 5,63 & 3,67 & 4,17 & 4,04 & 3,77 & 4,72 \\
T4 & 3,33 & 1,83 & 5,71 & 4,21 & 4,26 & 4,14 & 3,45 & 4,02 \\
T5 & 3,62 & 1,24 & 5,96 & 4,38 & 4,05 & 4,35 & 3,71 & 4,41 \\
T6 & 3,82 & 1,58 & 5,93 & 4,40 & 4,39 & 4,36 & 4,25 & 3,98 \\
T7 & 3,46 & 1,59 & 5,06 & 4,86 & 4,37 & 4,41 & 4,49 & 5,01 \\
T8 & 1,99 & 1,99 & 2,76 & 2,76 & 3,21 & 3,21 & 3,74 & 3,74 \\
\hline
\end{tabular}

Table 2. Soil resistance to penetration $(\mathrm{MPa})$ of a soil submitted to seven different treatments, evaluated at two different times of conduction of the experiment. T1 Limpograss; T2 - Tifton; T3 - Pensacola; T4-Limpograss + Pinto peanut; T5 - Tifton + Pinto peanut; T6 - Pensacola + Pinto peanut; T7 - Pensacola + Fallow treatment (Brachiaria humidicula + Brachiaria brizanta) + Pinto peanut; T8 - soil without cover crops. From: Gonçalves et al. (2007).

The continuous use of cover crops in farming systems that adopt the NT as management, tends to provide better physical qualities to soil, however, the mulch must be sufficient to maintain soil structure and prevent the formation of compacted layer, otherwise it may lead to increased soil bulk density, reducing the porosity (Kluthcouski \& Stone, 2003), resulting in lower moisture retention and increased soil resistance to penetration. Several studies (Derpsch et al. 1991; Kluthcouski, 1998; Vieira, 1985) show higher values of density and lower values of macroporosity in NT compared to conventional system.

The effect of cover crops may be more evident over the years when managed under NT, with increasing amounts of soil organic matter, which leads to increased aggregation of soil particles, reduction in soil density and increase of biological pores.

\subsection{Soil chemical attributes}

Cover crops in addition to soil physical attributes also influence in their chemical attributes, mainly acting as "biological pumps", nutrients cycling in the soil-plant system. The nutrients are absorbed through the root system of plants and brought to the surface after decomposition of plant residues. The system has a predominantly nutrient accumulation in the $0-5 \mathrm{~cm}$ layer, which can be confirmed by Sa (1993), that occurred after 4 and 16 years of implementing the $\mathrm{NT}$, increased levels of $\mathrm{P}$ in the $0-2.5 \mathrm{~cm}$, from $29 \mathrm{mg} \mathrm{dm}^{-3}$ to $129 \mathrm{mg} \mathrm{dm}^{-3}$, respectively. The effectiveness of cover crops on nutrient cycling is related to their morphological and physiological characteristics, particularly in relation to root growth and biomass production of shoots. According to Favero et al. (2000), nutrient accumulation is proportional to the amount of biomass produced and the efficiency of absorption of nutrients, which vary among species. Table 3 shows the amounts of nutrients absorbed by different species.

The effect of nutrient cycling is not only in the fact of increasing their availability, but also in the form these are made available. In the decomposition of plant residues, many nutrient are released in organic form, especially nitrogen $(\mathrm{N})$. Another element that is benefited from the mulch and plant cover is $\mathrm{P}$, since in this system there is moisture retention, reduction in contact with ion surfaces with clay charged surfaces, reducing their adsorption (fixation), 


\begin{tabular}{|c|c|c|c|c|c|c|}
\hline \multirow{2}{*}{ Cover crops } & \multicolumn{6}{|c|}{ Days after sowing } \\
\hline & 60 & 75 & 90 & 120 & 180 & 200 \\
\hline & \multicolumn{6}{|c|}{ Nitrogen $\left(\mathrm{kg} \mathrm{ha}^{-1}\right)$} \\
\hline B. ruziziensis & 58,7 & 140,8 & 130,2 & 113,9 & 96,3 & 155,9 \\
\hline B. brizantha & 52,0 & 123,0 & 144,7 & 171,7 & 137,5 & 142,8 \\
\hline P.glaucum & 148,8 & 96,2 & 61,5 & 60,8 & 44,5 & 38,1 \\
\hline \multirow[t]{2}{*}{ Fallow } & 16,3 & 37,9 & 35,0 & 34,0 & 17,9 & 35,8 \\
\hline & \multicolumn{6}{|c|}{ Phosphorus (kg ha-1) } \\
\hline B. ruziziensis & 8,6 & 11,0 & 9,7 & 6,4 & 9,7 & 12,4 \\
\hline B. brizantha & 8,0 & 12,8 & 10,5 & 14,7 & 8,1 & 13,5 \\
\hline P.glaucum & 35,1 & 27,1 & 13,5 & 13,3 & 8,1 & 6,9 \\
\hline \multirow[t]{2}{*}{ Falow } & 2,7 & 3,3 & 3,2 & 4,3 & 1,7 & 4,1 \\
\hline & \multicolumn{6}{|c|}{ Potassium(kg ha-1) } \\
\hline B. ruziziensis & 40,3 & 78,8 & 91,1 & 84,6 & 60,4 & 118,9 \\
\hline B. brizantha & 25,2 & 88,8 & 87,7 & 143,8 & 90,6 & 126,6 \\
\hline P.glaucum & 135,1 & 80,6 & 59,6 & 55,5 & 32,5 & 23,4 \\
\hline \multirow[t]{2}{*}{ Falow } & 5,1 & 24,5 & 27,7 & 29,7 & 20,6 & 26,8 \\
\hline & \multicolumn{6}{|c|}{ Calcium (kg ha-1) } \\
\hline B. ruziziensis & 16,1 & 31,9 & 53,5 & 39,7 & 46,9 & 63,37 \\
\hline B. brizantha & 8,2 & 27,9 & 41,1 & 39,6 & 52,1 & 91,29 \\
\hline P.glaucum & 55,4 & 31,1 & 27,2 & 22,7 & 21,0 & 17,67 \\
\hline \multirow[t]{2}{*}{ Falow } & 5,3 & 10,9 & 30,21 & 26,3 & 20,2 & 26,11 \\
\hline & \multicolumn{6}{|c|}{ Magnesium (kg ha-1) } \\
\hline B. ruziziensis & 6,3 & 28,2 & 34,9 & 33,1 & 26,5 & 35,17 \\
\hline B. brizantha & 6,2 & 30,9 & 38,8 & 61,8 & 54,3 & 58,78 \\
\hline P.glaucum & 47,8 & 27,7 & 18,6 & 16,8 & 15,7 & 13,45 \\
\hline Falow & 1,8 & 6,5 & 7,5 & 12,1 & 7,6 & 14,51 \\
\hline
\end{tabular}

Table 3. Nutrient accumulation in biomass cover crops sowed after soybean harvest, measured at six times during the off season. From: Pacheco et al. (2009).

and an increase on the availability of P- inorganic layer (cycling) and P-organic in deeper layers (root exudation). The $\mathrm{K}$ is the nutrient with the largest and fastest return to the soil with the decomposition of cover crops (Figure 12). This is because it is not part of any organic compound in plants. The $\mathrm{K}$ cycling through the cover crop is very important, since the loss by leaching in soils of the cerrado is intense.

The accumulation of biomass by cover crops contributes to increase in OM content; however, this is dependent on management to be adopted in the culture system and the $\mathrm{C} / \mathrm{N}$ ratio of plant residues. The incorporation of crop residues results in loss of $\mathrm{C}$, which is already naturally high in Cerrado conditions due to high temperatures (Torres et al., 2005). The increase in content OM is very important in Cerrado conditions due to the low cation exchange capacity (CEC) and anion (AEC) originated from clay and sandy soils of low activity, and represents about $80 \%$ of CEC of these soils. The possible increase of CEC and AEC with the use of cover crops resulted in greater availability of nutrients. Testa et al. (1992) observed proportional increases in the levels of $\mathrm{Ca}, \mathrm{Mg}$ and $\mathrm{K}$ as a result of a higher CEC. Heinrichs et al. (2005) observed an increase in levels of $\mathrm{P}$ and $\mathrm{K}$ after the implantation of cover crops in consortium. Yet, Santos \& Smith (1996), after four years of NT in soil 


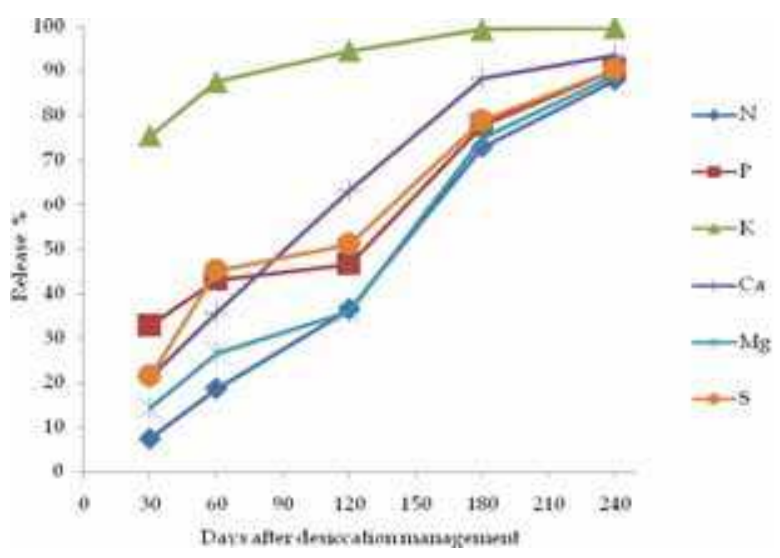

Fig. 12. Percentage of nutrients released from the millet residues, until 240 days after management. From: Adapted from Boer et al. (2007).

organic matter with more than $40 \mathrm{~g} \mathrm{~kg}^{-1}$ found no effect on soil chemical attributes. Given this, it is evident the greater effect of cover crops in soils with low OM contents.

Effect of cover crops on the NT is also observed in the reduction of acidity and toxic aluminum (Franchini et al. 1999; Salet, 1998; Sumner \& Pavan, 2000). According to Miyazawa et al. (2000), the ability of cover crops residues in reducing soil acidity is related to the concentration of basic cations and soluble organic carbon. Another interesting aspect of plant residues is the fact that due to its amphoteric characteristic a $\mathrm{pH}$ reduction occurs in alkaline soils and a $\mathrm{pH}$ increase in acidic soils.

It is noteworthy that the cover crops on the NT managed do not recover the chemical fertility of the soil , especially in the Cerrado, where there are naturally poor soils (Kluthcouski \& Stone, 2003), and for the successful establishment of the NT it is necessary to correct the initial attributes of soil fertility. The increase of the productive potential of these soils is mainly the effect of CEC increase caused by an increase in soil organic matter.

\subsection{Soil biological attributes}

Keeping mulch on the soil surface through cover crops contribute to the physical and chemical characteristics of soil improvements, it also stimulates the activity of soil microorganisms, serving as an energy source, thereby altering the activity of micro and mesofauna and mainly by increasing microbial diversity. Microorganisms' activities in Cerrado conditions that are already high, become even greater by the presence of cover crops. This generates intense ground motion, contributing to the increase of biological pores, which store different organic compounds that will be decomposed and mineralized, contributing to the improvement of chemical characteristics of the soil.

The effect of cover crops and different management systems can be evidenced by the activity of microorganisms by analysis of soil quality indicators. According to De-Polli \& Pimentel (2005), it is essential to dispose of sustainability indicators of soil, indicating the degree of conservation of a particular management system. Among the various biological attributes that are influenced by human activity through changes in management systems, stands out $\mathrm{C}$ and $\mathrm{N}$ microbial biomass, respiration rate $\left(\mathrm{CO}_{2}\right.$ emission or $\mathrm{O}_{2}$ consumption), 
microbial quotient (qMIC) (De-Polli \& Pimentel, 2005, Karlen et al., 1997) and metabolic quotient (qCO2), considered by Anderson \& Domsch (1993) as a biological indicator of human activity more precisely on the soil microbial activity, which is the ratio of respiration basal unit of microbial biomass per unit of time. This parameter also indicates the degree of "stress" of the microbial community. Changes in soil biological parameters as a function of cover crops and soil management can be seen in Table 4.

In NT one should be aware of the effect on the proliferation of pathogenic fungi in the soil, due to the favorable microclimate provided with the maintenance of straw on the soil surface.

\begin{tabular}{ccccc}
\hline $\begin{array}{c}\text { Soil management } \\
\text { system }\end{array}$ & $\begin{array}{c}\text { C-Microbial } \\
\text { biomass }\end{array}$ & $\begin{array}{c}\text { N- Microbial } \\
\text { biomass }\end{array}$ & Respiration rate & $q \mathrm{CO}_{2}$ \\
\cline { 2 - 5 } & $(\mathrm{C}-\mathrm{BM} \mu \mathrm{g}$ g soil-1) & $(\mathrm{N}-\mathrm{BM} \mu \mathrm{g}$ g soil-1) & $\left({\left.\mathrm{C}-\mathrm{CO}_{2} \mu \mathrm{g} \text { g solo-1 } \mathrm{h}^{-1}\right)}\right.$ \\
\hline No-tillage (NT) & 292 & 32 & 6,9 & 0,027 \\
$\begin{array}{c}\text { Conventional } \\
\text { tillage }(\mathrm{CT})\end{array}$ & 262 & 29 & 8,1 & 0,045 \\
\hline
\end{tabular}

Table 4. Carbon and nitrogen microbial biomass, respiration rate and metabolic quotient (qCO2) in two soil management systems: no tillage (NT) and conventional tillage (CT). From: Adapted from Silva et al. (2007).

\section{Suppression and weeds control by cover crops}

The presence of mulch on the soil surface reduces the development of weeds, mainly due to physical impairment. Cover crops that result in greater amount of organic residues and with high $\mathrm{C} / \mathrm{N}$ ratios are more efficient in the management of invasive plants, by composing a thicker layer of mulch on the soil surface and a longer time of permanence. According to Oliveira et al. (2002), the number of weeds decreases linearly with increasing amount of organic residues on surface soil, as can be seen in Figure 13.

The maintenance of cover crops generates competition with weeds for water, light, $\mathrm{CO} 2$, mainly physical space, leading to a delay in their development. Besides the suppression (physical effects) of cover crops on weeds, there is also the influence of chemical compounds released by plants, called allelopathic effect. According to Tokura \& Nobrega (2006), the residual plant cover is of great importance on allelopathic weeds.

According to Moraes et al. (2010), the allelopathic effect depends on the amount of cover crop residues produced, on the weed species that can be observed in the soil seed bank, and on the time of decomposition of soil residues. Rao et al. (2003) observed that the slow decomposition of plant residues can lead to a longer period of allelopathy on weeds, provided that the critical levels of allelochemicals are achieved.

The allelochemicals present in plants can be released to soil via root exudation, volatilization, leaching and decomposition of plant residues. These compounds are water soluble and can remain in soil solution and be absorbed by the root system of weeds. The allelochemicals cause physiological and morphological changes, influencing processes such as germination, growth, flowering, fruiting, senescence and abscission sensitive species (Correia et al., 2005). Table 5 and Figure 14 show the effects of cover crops on the germination and development of Bidens sp. An important weed in the Cerrado, once they have arisen frequently resistant biotypes which are resistant to herbicides inhibiting acetolactate synthase (ALS), the main herbicides used to control this species. 


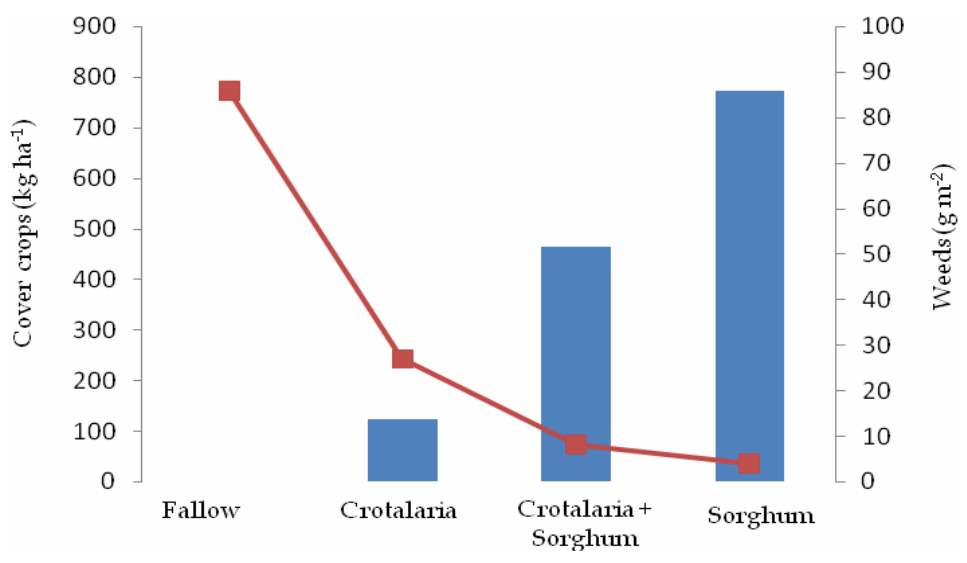

Fig. 13. Weed biomass reduction by the amount of cover crops residues on soil surface. From: Adapted from Goulart et al. (2009).

\begin{tabular}{lccc}
\hline Treatment & \% Germination & GSI & \% Germination reduction \\
\hline Fallow & 87,8 & 28,8 & 0,0 \\
Cajanus cajan & 82,2 & 28,0 & 6,3 \\
Crotalária spectabilis & 75,5 & 20,9 & 14,0 \\
Styzolobium atterrimum & 67,9 & 19,0 & 22,6 \\
Crotaláriajuncea & 56,6 & 19,4 & 35,5 \\
\hline
\end{tabular}

Table 5. Germination percentage, germination speed index (GSI) and percentage reduction of the germination of achenes of Bidens pilosa under the effect of aqueous extracts of different plants as green manure. From: Adapted from Teixeira et al. (2004).

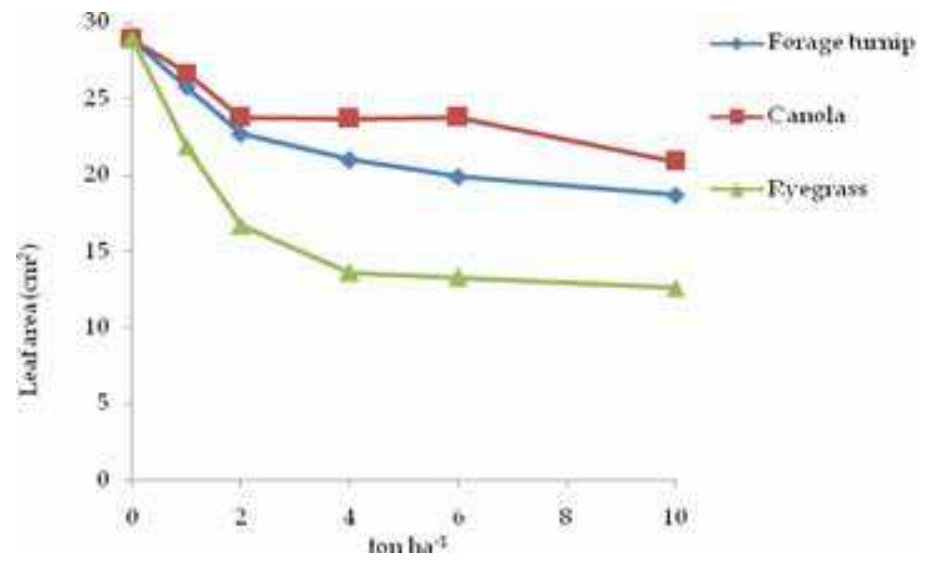

Fig. 14. Leaf area of Bidens sp., in different amount of cover crops residues on the soil surface. From: Adapted from Moraes et al. (2010). 


\section{Performance of soybean cropped under cover crops}

The soybean productivity under different tillage systems depends among other factors, on climate, soil type, soil fertility, pest management, finally, on the technological level of dealing with crops.

The response of soybean to the NT becomes more evident in tropical weather conditions, such as the Cerrado, due to poor and naturally acid soil, low in organic matter, since there is a high microbial activity and often harsh conditions of humidity, which are often mitigated by the use of cover crops that help retain moisture, increase organic matter and therefore fertility, reduce soil temperature variation, increase microbial activity resulting in the release of plant nutrients and lower density layers throughout the soil profile. The increase in soil organic matter of humic substances can lead to the occurrence of the electrophysiological effect, which reduces the energy required by plants while absorbing nutrients, resulting in a higher amount of assimilates to be distributed to sinks (grain). According to Nardi et al. (2002), low molecular weight compounds derived from humic substances can aid the absorption of nutrients through the plasma membrane, such as $\mathrm{NO}_{3}$. Some studies (Marcandali et al. 2010; Pacheco et al. 2009) have demonstrated the superiority of soybean when grown under NT. In the Cerrado, there has been highlighted as cover crop, the millet and brachiaria, providing the best yields for soybeans (Figure 15).

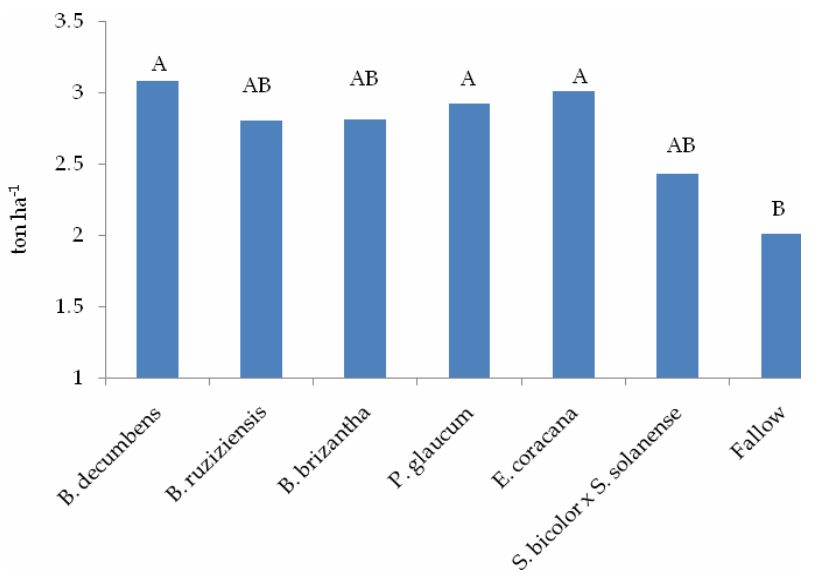

Fig. 15. Soybean productivity (ton ha-1) grown under different cover crops.From: Adapted from Pacheco et al. (2009).

The capacity of cover crop species used in NT influences significantly in soybean production (Fig.16), since the higher covering rate is associated with higher biomass quantities, providing better building conditions to the soil.

The costs of implementing the NT initially raise production costs in comparison to conventional systems. The high initial cost of adopting the NT is due to the need for soil conditioning and the acquisition of appropriate machines (Fidelis et al., 2003). However, these costs are significant only in short term, because over the years ( $>3$ years) that cost becomes low when compared to conventional systems, if considered the benefits that the cover crop system provides to physical, chemical and biological soil attributes, thus increasing the revenue (Figure 17). 


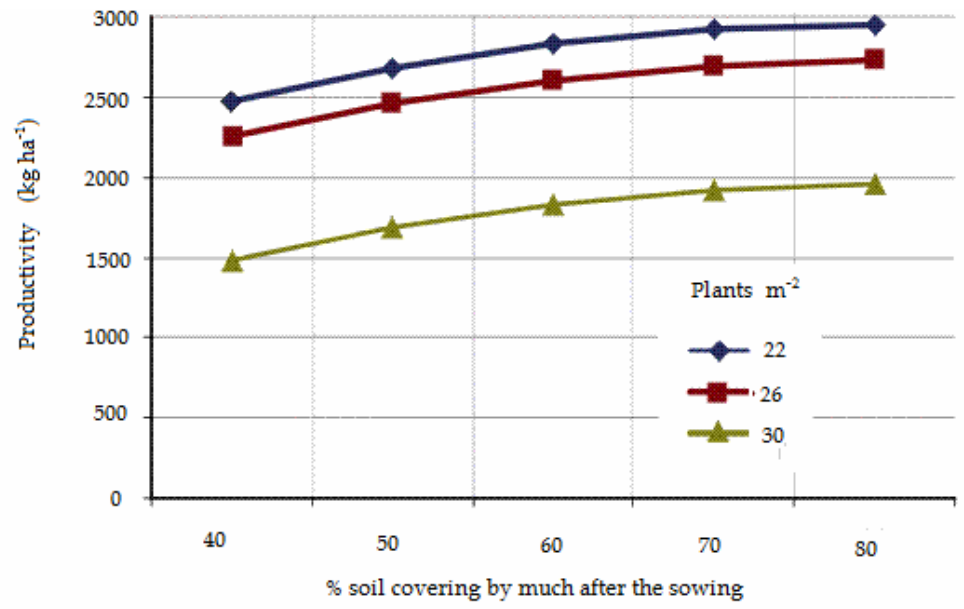

Fig. 16. Increased productivity of soybean due to higher mulch immediately after seeding it in no-till. From: Adapted from Medeiros \& Calegari (2007).

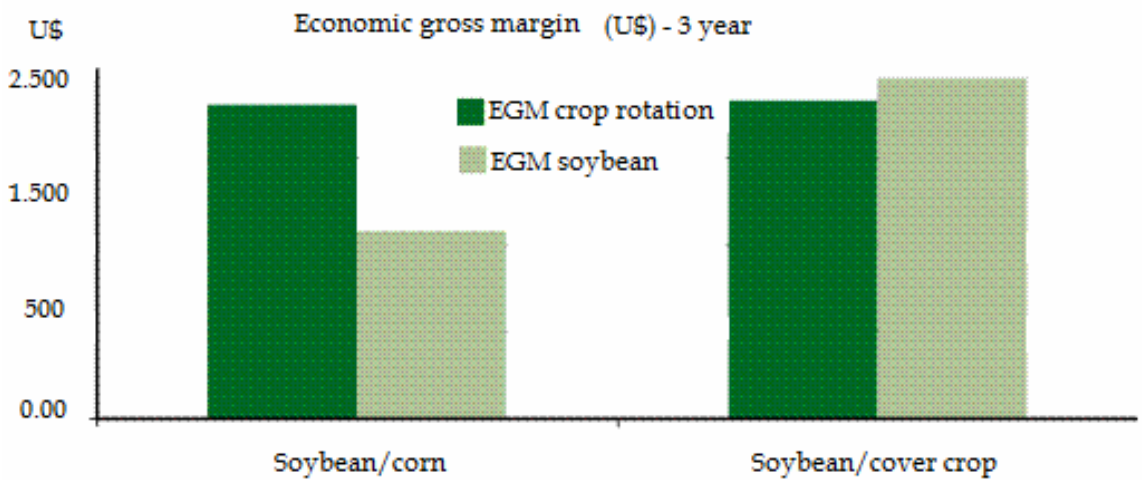

Fig. 17. Economic gross margin for soybean in two production systems, soybean/ corn in double-cropping and soybean/ cover crops in double-cropping, for three consecutive years. From: Adapted from Medeiros \& Calegari (2007).

\section{References}

Aita, C. \& Giacomini, J. (2003). Decomposição e liberação de nitrogênio de resíduos culturais de plantas de cobertura do solo solteiras e consorciadas. Revista Brasileira de Ciência do Solo, Vol.27, No.4, (July 2003), pp. 601-612, ISSN 0100-0683

Aita, C. \& Giacomini, J. (2006). Plantas de cobertura de solo em sistemas agrícolas, In: Manejo de sistemas agrícolas, B.J.R. Alves; S. Urquiaga; C. Aita; R.M. Boddey; C.P. Jantalia \& F.A.O. Camargo (Eds), 59-80, Genesis, ISBN 85-87578-13-8

Amabile, R. F.; Fancelli, A. L. \& Carvalho, A. M. (2000). Comportamento de espécies de adubos verdes em diferentes épocas de semeadura e espaçamentos na região dos 
cerrados. Pesquisa Agropecuária Brasileira, Vol.35, No.1, (January 2000), pp. 47-54, ISSN 0100-204X

Amado, T. J. C., Bayer, C., Eltz, F. L. F. \& Brum, A. C. R. (2001). Potencial de culturas de cobertura em acumular carbono e nitrogênio no solo no plantio direto e a melhoria da qualidade ambiental. Revista Brasileira de Ciência do Solo, V. 25, No. 1, (janeiro/ fevereiro 2001), pp. 189-197, ISSN 0100-0683.

Anderson, T. H. \& Domsch, K. H. (1993). The metabolic quotient for $\mathrm{CO}_{2}\left(\mathrm{qCO}_{2}\right)$ as a specific activity parameter to assess the effects of environmental conditions, such $\mathrm{pH}$, on the microbial of forest soils. Soil Biology and Biochemistry, Elmsford, Vol.25, No.3, (March 1993), pp.393- 395, ISSN 0038-0717

Andrews, J. A., JohnsoN, J. E. \& Torbert, T. L. 1998. Minesoil and site properties associated with early height growth of eastern white pine. eburnal Environmental Quality, Vol.27, No.1 (January 1998), pp. 192-199, ISSN 0047-2425

Bell, J. C., Conningham, R. L. \& Antony, C. T. (1994). Morphological characteristics of reconstructed prime farmland soils in western Pennsylvania. eburnal Environmental Quality, Vol.23, No.3, (March 1994), p. 515-520, ISSN 0047-2425

Bloom, A. J.; Smart, D. R.; Nguyen, D. T. \& Searles, P. S. Nitrogen assimilation and growth of wheat under elevated carbon dioxide. (2002). Plant Biology, Vol.99, No.12, (December 2002), pp. 1730-1735, ISSN 1438-8677

Boer, C. A.; Assis, R. L.; Silva, G. P.; Braz, A. J. B. P.; Barroso, A. L. L.; Cargnelutti Filho, A. \& Pires, F. R. (2007). Ciclagem de nutrientes por plantas de cobertura na entressafra em um solo de cerrado. Pesquisa Agropecuária Brasileira., Vol.42, No.9, (September 2007), pp. 1269-1276, , ISSN 0100-204X

Bordin, I.; Neves, C. S. V. J.; Francio Filho, P.; Preti, E. A. \& Cardoso, C. (2008). Crescimento de milheto e guandu, desempenho de plantas cítricas e propriedades físicas do solo escarificado em um pomar. Revista Brasileira de Ciência do Solo, Vol.32, No.4, (July 2008), pp. 1409-1418, , ISSN 0100-0683

Braz, A. J. B. P.; Silveira, P. M. da; Kliemann, H. J. \& Zimmermann, F. J. P. (2004). Acumulação de nutrientes em folhas de milheto e dos capins braquiária e mombaça. Pesquisa Agropecuária Tropical, Vol.34, No.1, (March 2004), pp. 83-87, ISSN 1983-4063

Campos, B. C.; Reinert, D. J.; Nicolodi, R.; Ruedell, J. \& Petrere, C. (1995). Estabilidade estrutural de um latossolo vermelho-escuro distrófico após sete anos de rotação de culturas e sistemas de manejo de solo. Revista Brasileira de Ciência do Solo, Vol.19, No.1, (January 1995), pp. 121-126, ISSN 0100-0683

Carneiro, M. A. C.; Souza, E. D.; Reis, E. F.; Pereira, H. S. \& Azevedo, W. R. (2009). Atributos físicos, químicos e biológicos de solo de cerrado sob diferentes sistemas de uso e manejo. Revista Brasileira de Ciência do Solo, Vol.33, No.1, (January 2009), pp. 147-157, ISSN 0100-0683

Carpenedo, V. \& Mielniczuk, J. (1990). Estado de agregação e qualidade dos agregados de Latossolos roxos, submetidos a diferentes sistemas de manejos. Revista Brasileira de Ciência do Solo, Vol.14, No.1 (January/ april 1990), pp. 99-105, ISSN 0100-0683

Carpim, L.; Assis, R. L.; Braz, A. J. B. P.; Silva, G. P.; Pires, F. R.; Pereira, V. C.; Gomes, G. V. \& Silva, A. G. (2008). Liberação de nutrientes pela palhada de milheto em diferentes estádios fenológicos. Revista Brasileira de Ciência do Solo, Vol.32, No. spe, (October 2008), pp. 2813-2819, ISSN 0100-0683 
Conab - Companhia Nacional de Abastecimento. (March 2009). 11 ${ }^{\circ}$ Levantamento da Produção de Grãos - Safra 2008/ 09. In; CONAB, 27.03. 2009, Available from:< http:/ / www.conab.gov.br>. Acesso em: 27 mar. 2009.

Correia, N. M., Centurion, M. A. P. C. \& Alves, P. L. C. A. (2005). Influência de extratos aquosos de sorgo sobre a germinação e o desenvolvimento de plântulas de soja. Ciência Rural, Vol.35, No.3, (May/ june2005), pp.498-503, ISSN 0103-8478

Costa, F. S.; Bayer, C.; Albuquerque, J. A. \& Fontoura S. M. V. (2004). Aumento de matéria orgânica num latossolo bruno em plantio direto. Ciência Rural, Vol.34, No.2, (April 2004), pp. 587-589, ISSN 0103-8478

Crawford, N. M. (1995). Nitrate: nutrient and signal for plant growth. The Plant Cell, Vol.7, No.7, (July 1995), pp. 859-868, ISSN 1532-298X

Crusciol, C. A. C.; Cottica, R. L.; Lima, E. V.; Andreotti, M.; Moro, E. \& Marcon, E. (2005). Persistência de palhada e liberação de nutrientes do nabo forrageiro no plantio direto. Pesquisa Agropecuária Brasileira, Vol.40, No.2, (February 2005), pp. 161-168, ISSN 0100-204X

De-Polli, H. \& Pimentel, M. S. (2005). Indicadores de qualidade do solo, In: Processos biológicos no sistema solo-planta: ferramentas para uma agricultura sustentável Aquino, A. M.; Assis, R. L. (Ed), pp. 17-28, ISBN 85-7383-304-1, Embrapa-SCT, Brasília, Brazil. Derpsch, R., Roth, C. H., Sidiras, N. \& Kopke, U. (1991). Controle da erosão no Paraná, GTZ, ISBN 3-88085-433-5, Eschborn, Germany

Dexter, A. R. (2004). Soil physical quality: Part II. Friability, tillage, tilth and hard-setting. Geoderma, Vol.120, No.3-4, (June 2004), pp.215-225, ISSN 0016-7061.

Espindola, J. A. A.; Guerra, J. G. M.; Almeida, D. L.; Teixeira, M. G. \& Urquiaga, S. (2006). Decomposição e liberação de nutrientes acumulados em leguminosas herbáceas perenes consorciadas com bananeira. Revista Brasileira de Ciência do Solo, Vol.30, No.2, (March 2006), pp. 321-328, ISSN 0100-0683

Falleiro, R. M.; Souza, C. M.; Silva, C. S. W.; Sediyama, C. S.; Silva, A. A. \& Fagundes, J. L. (2003). Influência dos sistemas de preparo nas propriedades químicas e físicas do solo. Revista Brasileira de Ciência do Solo, Vol.27, No.6, (November 2003), pp. 10971104, ISSN 0100-0683

Favero, C., Jucksch, I., Costa, L. M., Alvarenga, R. C. \& Neves, C. L. (2000). Crescimento e acúmulo de nutrientes por plantas espontâneas e por leguminosas utilizadas para adubação verde. Revista Brasileira de Ciência do Solo, Vol.24, No.1, (January/ april 2000), pp. 171-177, ISSN 0100-0683

Febrapdp - Federação Brasileira de Plantio Direto na Palha. (October 2009). Desenvolvimento do Plantio Direto. In: FEBRAPD, 03.10.2009. Available from:< http:/ / www.febrapdp.org.br>

Fidelis, R. R., Rocha, R. N. C., Leite, V. T. \& Tancredi, F. D. (2003). Alguns aspectos do Plantio Direto para a cultura da soja. Bioscience eburnal, Vol.19, No.1, January/ april 2003), pp. 23-31, ISNN 1981-3163

Franchini, J. C., Malavolta, E., Miyazawa, M. \& Pavan, M. A. (1999). Alterações químicas em solos ácidos após a aplicação de resíduos vegetais. Revista Brasileira de Ciência do Solo, Vol.23, No.3, (September/ december 1999), pp. 533-542, ISSN 0100-0683

Franco, A. A. \& Campello, E. F. C. (2005). Manejo integrado na recuperação de áreas degradadas e na sustentabilidade de sistemas produtivos utilizando a fixação biológica de nitrogênio como fonte de nitrogênio, In: Processos biológicos no sistema 
solo-planta: Ferramentas para uma agricultura sustentável, Aquino, A. M. \& Assis, R. L., pp. 201-220, Embrapa Informação Tecnológica, ISBN: 85-7383-304-1, Brasília, Brazil

Gama-Rodrigues, A. C.; Gama-Rodrigues, E. F. \& Brito, E. C. (2007). Decomposição e liberação de nutrientes de resíduos culturais de plantas de cobertura em argissolo vermelho-amarelo na região Noroeste Fluminense (RJ). Revista Brasileira de Ciência do Solo, Vol.31, No.6, (November 2007), pp. 1421-1428, ISSN 0100-0683

Giacomini, S. J.; Aita, C.; Hubner, A. P.; Lunkes, A.; Guidini, E. \& Amaral, E. B. (2003) Liberação de fósforo e potássio durante a decomposição de resíduos culturais em plantio direto. Pesquisa Agropecuária Brasileira, Vol.38, No.9, (September 2003), pp. 1097-1104, ISSN 0100-204X

Gonçalves, W. G.; Jimenez, R. L.; Araújo Filho, J. V.; Assis, R. L.; Silva, G. P. \& Pires, F. R. (2006). Sistema radicular de plantas de cobertura sob compactação de solo. Engenharia Agrícola, Vol.26, No.1, (January 2006), pp. 67-75, ISSN 0100-6916. Goulart, P., Campos, S., Bastiani, M., Moreira, G. \& Pereira, L. (2009). Desempenho da Biomassa das Plantas de Cobertura de Verão na Supressão de Plantas Espontâneas. Revista Brasileira De Agroecologia, Vol. 4, No. 2, (novembro 2009), p. 3494-3498, ISSN 1980-9735.

Heinrichs, R., Vitti, G. C., Moreira, A., Figueiredo, P. A. M., Fancelli, A. L. \& Corazza, E. J. (2005). Características químicas de solo e rendimento de fitomassa de adubos verdes e de grãos de milho, decorrente do cultivo consorciado. Revista Brasileira de Ciência do Solo, V. 29, No. 1, (January/ february 2005) pp. 71-79, ISSN 0100-0683

Henriksen, I.; Michelsen, A. \& Scholonvoigt, A. (2002). Tree species selection and soil tillage in alley cropping systems with Phaseolus vulgaris L. in a humid premontane climate: bimass production, nutrient cycling and croop responses. Plant Soil, Vol.240, No.1, (January 2002), pp. 145-159, ISSN 1573-5036

Karlen, D. L., Mausbach, M. J., Doran, J. W., Cline, R. G., Harris, R. F. \& Schuman, G. E. (1997). Soil quality: a concept, definition, and framework for evaluation. Soil Science Society of America eburnal, V. 61, No. 01, (January 1997), pp. 4-10, ISSN 0361-5995

Kluthcouski, J.; Fancelli, A. L.; Dourado-Neto, D.; Ribeiro, C. R. \& Ferraro, A. (2000). Manejo do solo e o rendimento de soja, milho, feijão e arroz em plantio direto. Scientia Agricola, Vol.57, No.1, (January 2000), pp. 97-104, ISSN 0103-9016

Kluthcouski, J. \& Stone, L. F. (2003). Manejo Sustentável dos Solos do Cerrado, In: Integração Lawoura-Pecuória, Kluthcouski, J., Stone, L. F. \& Aidar, H., pp. 61-104, Embrapa Arroz e Feijão, ISBN 85-7437-018-5, Santo Antônio de Goiás, Brazil

Kluthcouski, J. (1998). Efeito do manejo em alguns atributos de um latossolo roxo sob cerrado e nas características produtivas de milho, soja, arroz e feijão, após oito anos de plantio direto. 170 f. Thesis (Agronomy). Escola Superior de Agricultura "Luiz de Queiroz"

Machado, L. A. Z. \& Assis, P. G. G. (2010). Produção de palha e forragem por espécies anuais e perenes em sucessão à soja. Pesquisa Agropecuária Brasileira, Vol.45, No.4, (April 2010), pp. 415-422, ISSN 0100-204X

Marcandali, L. H., Lazarini, E., Franzola, F. H., Oliveira, W. A. S. \& Hayashi, F. K. (2010). Sistema Plantio Direto com Soja: características agronômicas e produtividade, Proceedings of XXIX Reunião Brasileira de Fertilidade do Solo e Nutrição de Plantas. Guarapari, ES, Brazil, 13-17 september 2010 
Medeiros, G. B. \& Calegari, A. 2007. Sistema Plantio Direto com qualidade: a importância do uso de plantas de cobertura num planejamento cultural estratégico. Revista Plantio Direto, Ed. 102, (November/ december 2007)

Menezes, L. A. S. \& Leandro, W. M. (2004).Avaliação de espécies de coberturas do solo com potencial de uso em sistema de plantio direto. Pesquisa Agropecuória Tropical, Vol.34, No.3, (September 2004), pp. 173-180, ISSN 1983-4063

Moraes, P. V. D., Agostinetto, D., Panozzo, L. E., Brandolt, R., Tironi, S. P., Oliveira, C. \& Markus, C. (2010). Efeito alelopático de plantas de cobertura, na superfície ou incorporadas ao solo, no controle de picão-preto. Revista da Faculdade de Zootecnia, Veterinária Agronomia da Pontíficia Universidade católica de Urugauiana, V. 17, No. 1, (January/ march 2010), pp. 51-67, ISSN 0104-4257

Moreira, J. A. A., Aguiar, R. A., Stone, L. F., Bernardes, T. G., Pereira Filho, I. A. \& Cruz, J. C. (2009). Efeito de Diferentes Plantas de Cobertura do Solo Sobre Alguns Atributos do Solo em Sistema de Produção Orgânico. Revista Brasileira de Agroecologia, V. 4, No. 2, (January 2009), pp. 3748-3751, ISSN 1980-9735

Nardi, S.; Pizzeghello, D.; Muscolo, A.; Vianello, A. (2002). Physiological effects of humic substances on higher plants. Soil Biology \& Biochemistry, V.34, No.11, (November 2002), pp. 1527-1536, ISSN 0038-0717

Oliveira, T. K. de., Carvalho, G. J. \& Moraes, R. N. S. (2002). Plantas de cobertura e seus efeitos sobre o feijoeiro em plantio direto. Pesquisa Agropecuária Brasileira, V.37, No.8, (August 2020), pp. 1079-1087, ISSN 1678-3921.

Pacheco, L. P. (2009a). Arroz de terras altas cultivado em sucessão a plantas de cobertura em sistemas de manejo do solo. PhD Thesis (Crop Production), (December 2009), Federal University of Goiás, Brazil

Pacheco, L. P.; Pires, F. R.; Monteiro, F. P.; Procópio, S. O.; Assis, R. L.; Carmo, M. L. \& Petter, F. A. (2008)Desempenho de plantas de cobertura em sobressemeadura na cultura da soja. Pesquisa Agropecuária Brasileira, Vol.43, No.7, (July 2008) pp. 815-823, ISSN 0100-204X

Pacheco, L.P.; Pires, F.R.; Monteiro, F.P.; Procópio, S.O.; Assis, R.L.; Cargnelutti Filho, A.; Carmo, M.L. \& Petter, F.A. (2009b). Sobressemeadura da soja como técnica para supressão da emergência de plantas daninhas. Planta Daninha, Vol.27, No.3, (September 2009), pp. 455-463, ISSN 0100-8358

Pereira, F. A. R. \& Velini, E. D. (2003) Sistemas de cultivo no cerrado e dinâmica de populações de plantas daninhas. Planta Daninha, Vol.21, No.3, (September 2003), pp. 355-363, ISSN 0100-8358

Portes, T. A.; Carvalho, S. I. C.; Oliveira, I. P. \& Kluthcouski, J. (2000). Análise do crescimento de uma cultivar de braquiária em cultivo solteiro e consorciado com cereais. Pesquisa Agropecuária Brasileira, Vol.35, No.7, (July 2000), pp. 1349-1358, ISSN 0100-204X

Rezende, C. P., Pinto, J. C. \& Evangelista, A. R. (2003). Alelopatia e suas interações na formação e manejo de pastagens. Boletim agropecuório, pp.1-55, No.54, Lavras, MG, Brazil.

RicharT, A., Tavares FilhO, J., Brito, O. R., Llanillo, R. F. \& Ferreira, R. (2005). Compactação do solo: causas e efeitos. Semina: Ciências Agrárias, Vol.26, No.3, (July/ september 2005), pp. 321-344, ISSN 0101-3742. 
Sá, J. C. de M. (1993). Manejo da fertilidade do solo no Sistema Plantio Direto, In: EmbrapaCentro Nacional de Pesquisa de Trigo, pp. 37-60, Embrapa Trigo, Passo Fundo, RS, Brazil.

Salet, R. L. (1998). Toxidez de alumínio no sistema plantio direto. Thesis (Agronomy). Federal University of Rio Grande do Sul, Porto Alegre, RS, Brazil.

Santos, H. P. \& Siqueira, O. J. W. (1996). Plantio direto e rotação de culturas para cevada: efeitos sobre a fertilidade do solo. Revista Brasileira de Ciência do Solo, Vol.20, No.2, (May/ august 1996), pp.163-169, ISSN 0100-0683

Severino, F. J.; Carvalho, S. J. P. \& Christoffoleti, P. J. (2006). Interferências mútuas entre a cultura do milho, espécies forrageiras e plantas daninhas em um sistema de consórcio. II - Implicações sobre as espécies forrageiras. Planta Daninha, Vol.24, No.1, (January 2006), pp. 45-52, ISSN 0100-8358

Silva, M. B., Kliemann, H. J., Silveira, P. M. \& Lanna, A. C. (2007). Atributos biológicos do solo sob influência da cobertura vegetal e do sistema de manejo. Pesquisa Agropecuória Brasileira, Vol.42, No.11, (November 2007), pp.001-007, ISSN 1678-3921

Stone, L. F. \& Silveira, P. M. (1999). Efeitos do sistema de preparo na compactação do solo, disponibilidade hídrica e comportamento do feijoeiro. Pesquisa Agropecuória Brasileira, Vol.34, No.1, (January 1999), pp. 83-91,ISSN 0100-204X

Sumner, M. E. \& Pavan, M. A. (2000). Alleviating soil acidity through organic matter management, Proceedings of $3^{\circ}$ Simpósio sobre Rotação Soja/Milho no Plantio Direto, Piracicaba, 3-5 julho 2000

Teixeira, C. M., Araújo, J. B. S. \& Carvalho, G. J. (2004). Potencial alelopático de plantas de cobertura no controle de picão-preto (Bidens pilosa L.). Ciência e Agrotecnologia, Vol.28, No.3, (May/ June 2004), pp. 691-695, ISSN 1413-7054

Testa, V. M., Teixeira, L. A. J.\& Mielniczuk, J. (1992). Características químicas de um Podzólico vermelho escuro afetadas por sistemas de culturas. Revista Brasileira de Ciência do Solo, Vol.16, No.2, (May/ august 1992), pp. 107-114, ISSN 0100-0683

Timossi, P.C.; Durigan, J.C. \& Leite, G.J. (2007). Formação de palhada por braquiárias para adoção do sistema plantio direto. Bragantia, Vol.66, No.4, (October 2007), pp. 617622, ISSN 0006-8705

Tokura, L. K. \& Nobrega, L. H. P. (2006). Alelopatia de cultivos de cobertura vegetal sobre plantas infestantes. Acta Scientia Agronômica, Vol.28, No.3, (October/ december 2006), pp. 379-384, ISSN 1679-9275

Torres, J.L.R.; Pereira, M.G.; Andrioli, I.; Polidoro, J.C. Fabian, A.J. (2005). Decomposição e liberação de nitrogênio de resíduos culturais de plantas de cobertura em um solo de cerrado. Revista Brasileira de Ciência do Solo, Vol.29, No.4, (July 2005), pp. 609-618, ISSN 0100-0683

Torres, J.L.R.; Pereira, M.G. \& Fabian, A.J. (2006). Produção de fitomassa por plantas de cobertura e mineralização de seus resíduos em plantio direto. Pesquisa Agropecuária Brasileira, Vol.43, No.3, (March 2008), pp. 421-428, ISSN 0100-204X

Vieira, M. J. 1985. Comportamento físico do solo em plantio direto, In: Atualização em plantio direto, Fancelli, A. L., Torrado, P. V. \& Machado, J., pp. 163-179, Fundação Cargil, Campinas, Brazil. 


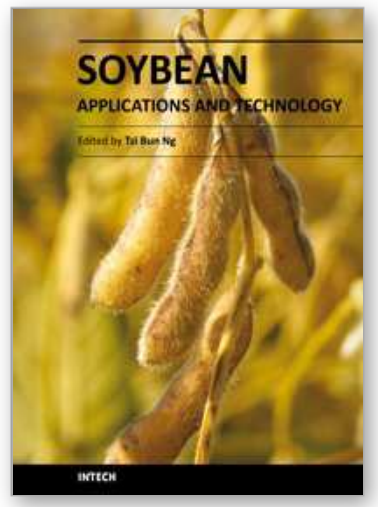

\author{
Soybean - Applications and Technology \\ Edited by Prof. Tzi-Bun $\mathrm{Ng}$
}

ISBN 978-953-307-207-4

Hard cover, 402 pages

Publisher InTech

Published online 26, April, 2011

Published in print edition April, 2011

Soybean is an agricultural crop of tremendous economic importance. Soybean and food items derived from it form dietary components of numerous people, especially those living in the Orient. The health benefits of soybean have attracted the attention of nutritionists as well as common people.

\title{
How to reference
}

In order to correctly reference this scholarly work, feel free to copy and paste the following:

Pacheco, Leandro Pereira and Petter, Fabiano André (2011). Benefits of Cover Crops in Soybean Plantation in Brazilian Cerrados, Soybean - Applications and Technology, Prof. Tzi-Bun Ng (Ed.), ISBN: 978-953-307-207-4, InTech, Available from: http://www.intechopen.com/books/soybean-applications-and-technology/benefits-ofcover-crops-in-soybean-plantation-in-brazilian-cerrados

\section{INTECH}

open science | open minds

\section{InTech Europe}

University Campus STeP Ri

Slavka Krautzeka 83/A

51000 Rijeka, Croatia

Phone: +385 (51) 770447

Fax: +385 (51) 686166

www.intechopen.com

\section{InTech China}

Unit 405, Office Block, Hotel Equatorial Shanghai

No.65, Yan An Road (West), Shanghai, 200040, China

中国上海市延安西路65号上海国际贵都大饭店办公楼405单元

Phone: +86-21-62489820

Fax: $+86-21-62489821$ 
(C) 2011 The Author(s). Licensee IntechOpen. This chapter is distributed under the terms of the Creative Commons Attribution-NonCommercialShareAlike-3.0 License, which permits use, distribution and reproduction for non-commercial purposes, provided the original is properly cited and derivative works building on this content are distributed under the same license. 